\title{
EFFECT OF SOIL CONDITIONERS ON YIELD, WATER PRODUCTIVITY AND SOIL MOISTURE DISTRIBUTION PATTERNS OF CUCUMBER GROWN UNDER SUBSURFACE DRIP IRRIGATION ON A SANDY SOIL
}

\author{
M. E. Abuarab*; A. M. Abdel-Hameed; W. M. Sultan** and \\ M. A. Kassem***
}

\begin{abstract}
A field experiment was conducted in sandy soil in a private farm, El-Giza, Egypt, throughout two consecutive summer seasons for 2014 and 2015, to assess the impact of soil conditioners on cucumber (Cucmissativus l.) plants under subsurface drip irrigation. The drip lines treatments were (GR; GR anti-root; and T-tape), while the soil conditioners treatments were (Compost; Rice straw; Polymer; and Control). The result showed that the compost with Anti-roots treatment achieved highest yield, where the yield was greater by $20.12 \%, 34.42 \%$ and $57.31 \%$ comparing with rice straw, polymers, and control treatments, respectively, for the first season, while it was greater by $16.7 \%, 32.7$ and $53.8 \%$ than rice straw, polymers, and control treatments, respectively, for the second season. The water productivity under compost with GR anti-root treatment was greater by $10.16 \%$ and $11.8 \%$ comparing with compost with GR and compost with t-tape treatments, respectively, for the first season, while it was greater by $8.34 \%$ and $9.5 \%$ than compost with GR and compost with t-tape treatments, respectively, for the second season. Data from this study indicate that cucumber yield can be improved under subsurface drip irrigation by using compost and GR anti-root as drip line.
\end{abstract}

Keywords: Subsurface drip irrigation, soil conditioners, cucumber, water productivity, soil moisture distribution pattern.

\section{INTRODUCTION}

T The choice of appropriate irrigation method is the key-factor for irrigation water-saving and increase productivity in arid areas is irrigation systems have become more important.

\footnotetext{
* Associate Professor of Irrigation and Drainage Eng. - Faculty of Agric. - Cairo Univ.

** Associate Professor, Irrigation and Drainage Department, Agric. Eng. Research Institute. *** Professor of Irrigation and Drainage Eng. - Faculty of Agric. - Cairo Univ.
} 
There are definite difficulties in the sandy soil management, including excessive infiltration rate, low water and nutrient holding capacity (Suganya and Sivasamy, 2006). This system is known for its slow frequent addition of water to the soil through emitters placed along the lateral line under the soil surface (Neufeld et al., 1999).

SDI-system has a high water application efficiency that can contribute significantly to improving the efficiency of water use for crops and water conservation (Hanson and May, 2004). In respect of water losses by evaporation the surface drip irrigation is the most water-saving irrigation system. However, in sandy soils with low water holding capacity, the loss of water and nutrients due to leaching is a serious drawback (Schaumberger and Loiskandl, 2010).

Water scarcity led to use saline water for crop irrigation (Chen et al., 2010). The low quality of irrigation water adversely affects plant growth and crop productivity (Carmassi et al., 2010; Valdez-Aguilar et al., 2013). For instance, under irrigation with saline water, sodium ions $\left(\mathrm{Na}^{+}\right)$will pile up in plant tissues, and then shake the water absorption and reduce the absorption of essential nutrients such as nitrogen $(\mathrm{N})$, phosphorus $(\mathrm{P})$, potassium (K) and calcium (Ca) (Lakhdar et al., 2008). Furthermore, the buildup of sodium leads to a reduction of plant growth (Tejada et al., 2006; Chen et al., 2010). Therefore, it is important to find ways to reduce the negative effects of the water of low quality if used for irrigation purposes.

The application of organic matter as a soil conditioner is a common exercise in areas affected by salts to reduce the negative effects of saline water. The application of OMC has three main valuable effects on plant and soil system: (a) Improving salt leaching through refining soil permeability and structure (Walker and Bernal, 2008; Lakhdar et al., 2011), (b) suppling substantial nutrients for plants (Lakhdar et al., 2008), and (c) reestablishing microbial populations and activities (Lakhdar et al., 2009). Compost application in the salty soils can increase water infiltration, speed up leaching of sodium chloride, lower sodium exchangeable ratio and lower electrical conductivity (Hanson and May, 2004). Natural organic materials include animal dung, crop residues, organic compost, sawdust, food, and remnants of waste and 
manufacturing papers, all of which are used for soil reclamation to increase infiltration and retention of water, provide the foundation for biological activity, improve aeration, reduce soil strength and pressure resistance, and surface sealing. This is particularly important to improve the growing of crops in sandy soil (Akelah, 2013). Animals manure is known for enhancing plant growth in saline soils. It is also a source of nutrients that can mend soil fertility (Tejada et al., 2006; Walker and Bernal, 2008).

The best practices for the management of sandy soil are routine addition of organic matter, in order to help increase the capacity of sandy soil to retain water and nutrients. Soils that contain high percentages of organic matter (4-5\%) are considered ideal for gardens (David et al., 2011). Therefore to improve agricultural productivity and soil fertility it is necessary to add organic matter to the soil. However, because of limited resources of traditional organic materials such as animal manure, the use of other organic wastes such as sewage sludge, agricultural waste and industrial solid waste is growing (Baybordi et al., 2000). Among the organic manures, compost is the most important economical source of nitrogen. The use of chemical fertilizers and pesticides in agricultural ecosystems cause environmental pollution, soil erosion, result in contaminate food chain and result in pest resistance to pesticides. Human and environmental problems, arise the necessitates of non-chemical methods of soil fertilization. Application of organic manure and biological control, represents a vital role in this context (Greer and Diver, 2000).

Applying compost to the soil enhances soil composition and reduces bulk density (Caravaca et al., 2002). Heikal et al. (2008), reported that the affirmative impact of compost on increment of tuber productivity of potato is a true reflection of improving soil water retention due to its effect on pore size distribution i.e., water holding in pores.

Rice straw is the primary output organic waste of rice cultivation. Rice straw is an important source of nutrients (it contains $0.6 \%$ nitrogen, $0.1 \%$ each of phosphorus and sulfur, 1.5\% potassium, 5\% silica and 40\% carbon). Davies et al. (1993) reported that mulching through utilization of rice straw lead to increased soil moisture content, increase soil nutrients, 
improve the biological activity of the soil, and increased plant growth and consequently productivity. Esawy et al. (2009) reported that utilization of rice straw as organic manure, may have played an indispensable role not only in enhancing soil physical properties and soil-water holding capacity but also to the improvement of plant nutrients.

Super absorbent polymers (SAP) can raise soil-water capacity for sandy soil (Al-Omrana et al., 2004). El-Gindy et al. (2001) reported that sandy soil has a low ability to retain water and using soil conditioners especially polymers can increase their ability to retain water. The integration of polymer into the soil improves the soil assembly and water holding capacity, thus reducing leakage and consequently reducing water losses due to percolation, saving plant of water stress and increasing both nutrients and water supply to the roots. Zhang et al. (2006) reported that utilization of SAPs can renovate the sandy soil and lower irrigation water consumption, improving the retention of fertilizers in soil, reducing mortality rate of plants, and increased plant growth rate. Akhter et al. (2004) reported that application of soil conditioner with SAR can improve the setting up of plants in water-stressed regions. Superabsorbent compounds have been made through the metal merged with hydrogels to decrease manufacture costs and enhance the salt impedance, including fertilizers in the network of superabsorbent may therefore be an operational way to increase the efficient use of both water and fertilizer compounds (Akelah, 2013).

The objective of this research is to study the effect of using soil conditioners with saline water on cucumber yield, water productivity and soil moisture distribution patterns in sandy soil, this objective was achieved through the following specific aims: a) comparing the effectiveness of soil conditioners on water productivity for cucumber, b) study the effect of soil conditioners with saline water on vegetative growth parameters and yield of cucumber, and c) study the soil moisture distribution patterns in sandy soil.

\section{MATERIALS AND METHODS}

\subsection{Experimental location characteristics}

The research was proceeded from April to July 2014 and 2015 at ElHussein village (private farm), El-Giza, Egypt (latitude 29.97N, and 
31.13E longitudes). The soil of the experimental site has a deep soil profile, sandy soil with good drainage.

Mechanical analysis (sand, silt and clay) was determined according to the pipette method as described by Dewis and Fartias (1970). Soil reaction (pH) was measured in $1: 2.5$ (soil: water) suspension according to Jackson (1967). Total water soluble salts were measured by the electrical conductivity meter apparatus in soil paste extract (Richards, 1954). Soluble ions $\left(\mathrm{Na}^{+}, \mathrm{K}^{+}, \mathrm{Ca}^{+2}, \mathrm{Mg}^{+2}, \mathrm{CO}_{3}^{-2}, \mathrm{HCO}^{-3}, \mathrm{SO}_{4}^{-2}\right.$ and $\left.\mathrm{Cl}^{-}\right)$were determined according to Jackson (1967). Organic matter content (\%) was determined according to Wally and Black method as described by Hesse (1971). Soil bulk density and the bulk density of the mixture between soil and soil conditioners was determined using cylindrical sharp edged samples. Each cylinder was pressed gently into the soil to the desired depth to obtain a known volume of the undisturbed soil. Samples were oven dried at $105{ }^{\circ} \mathrm{C}$ and the bulk density calculated as $\mathrm{g} / \mathrm{cm}^{3}$ (Vomocil, 1957). Field capacity $\left(\Theta_{\mathbf{F C}}\right)$ and permanent wilting point $\left(\Theta_{\mathrm{PWP}}\right)$ were determined by using pressure membrane method (desorption) at 0.33 and $15 \mathrm{~atm}$, respectively (Klute, 1986).

Table 1 and 2 shows the physical and chemical properties of the soil of the experimental site and applied soil conditioners. The chemical composition of the soil conditioners represents that the compost has the highest organic matter with $22.6 \%$, followed by rice straw with $1.5 \%$, while polymer has no organic matter (Table 3 ). Irrigation water has been acquired from a deep well (60m depth from the soil surface) positioned at the experimental site, with $\mathrm{pH} 7.01$, and the mean electrical conductivity of $7.06 \mathrm{dS} . \mathrm{m}^{-1}$ (Table 4).

\subsection{Crop administration}

The Cucumber (Prince) variety (Cucmissativus l.) was used in field experiments. The cultivation of plants in the three-leaf stage on April 17th in each of the both growing seasons, in a single plot, the plot consists of 3 rows $(2.4 \mathrm{~m} \times 15 \mathrm{~m})$. According to that a distance of $80 \mathrm{~cm}$ between rows and $30 \mathrm{~cm}$ between plants on the same row were achieved, which gives the plant population of up to 41667 plants per hectare.

Fertilizers were added and mixed with the soil uniformly to all treatments, fertilizers used consists of $60 \mathrm{kgha}^{-1}$ chicken manure, $120 \mathrm{kgha}^{-1}$ actual $\mathrm{N}$ 
(as urea $46 \% \mathrm{~N}$ ), $150 \mathrm{kgha}^{-1} \mathrm{~K}_{2} \mathrm{O}, 180 \mathrm{kgha}^{-1} \mathrm{P}_{2} \mathrm{O}_{5}$, and $300 \mathrm{kgha}^{-1}$ was injected $\mathrm{kgha}^{-1} \mathrm{~N}$ using venturi through subsurface drip irrigation system underneath the soil surface in four equal installments over a period of fruiting (Wang et al., 2009).

Table 1. Soil textural classes, field capacity $\left(\theta_{\mathrm{FC}}\right)$, wilting point $\left(\theta_{\mathrm{WP}}\right)$ wilting point $\left(\theta_{\mathrm{WP}}\right)$, bulk density, $\mathrm{pH}$ and electrical conductivity.

\begin{tabular}{ccccccc}
\hline $\begin{array}{c}\text { Soil } \\
\text { depth } \\
(\mathbf{c m})\end{array}$ & Texture & $\begin{array}{c}\boldsymbol{\Theta}_{\mathrm{FC}} \\
\left(\mathbf{c m}^{\mathbf{3}} \cdot \mathbf{c m}^{-\mathbf{3}}\right)\end{array}$ & $\begin{array}{c}\boldsymbol{\Theta}_{\mathrm{PWP}} \\
\left(\mathbf{c m}^{\mathbf{3}} \cdot \mathbf{c m}^{-\mathbf{3}}\right)\end{array}$ & $\begin{array}{c}\text { Bulk } \\
\mathbf{d e n s i t y} \\
\left(\mathbf{g . c m}^{-\mathbf{3}}\right)\end{array}$ & $\mathbf{p H}$ & $\begin{array}{c}\text { ECe } \\
\left(\mathbf{d S} . \mathbf{m}^{-\mathbf{1}}\right)\end{array}$ \\
\hline $0-20$ & Sand & 10.7 & 3.1 & 1.62 & 7.65 & 2.16 \\
$20-40$ & Sand & 12.1 & 3.5 & 1.59 & 8.17 & 0.78 \\
$40-60$ & Sand & 11.9 & 3.5 & 1.58 & 8.12 & 1.01 \\
\hline
\end{tabular}

Table 2. Experimental soil characteristics after mixing with compost, rice straw and polymers.

\begin{tabular}{|c|c|c|c|c|c|}
\hline $\begin{array}{c}\text { Soil } \\
\text { condition } \\
\text { er } \\
\end{array}$ & $\begin{array}{c}\Theta_{\mathrm{FC}} \\
\left(\mathrm{cm}^{3} \cdot \mathrm{cm}^{-3}\right)\end{array}$ & $\begin{array}{c}\Theta_{\mathrm{PWP}} \\
\left(\mathrm{cm}^{\mathbf{3}} \cdot \mathbf{c m}^{-3}\right)\end{array}$ & $\begin{array}{c}\text { Bulk } \\
\text { density } \\
\left(\text { g.cm }^{-3}\right)\end{array}$ & pH & $\begin{array}{c}\text { ECe } \\
\left(\mathrm{dS} . \mathrm{m}^{-1}\right)\end{array}$ \\
\hline Compost & 19.3 & 6.3 & 1.65 & 7.17 & 2.1 \\
\hline Rice straw & 18.9 & 5.4 & 1.67 & 7.49 & 7.53 \\
\hline polymers & 21.3 & 7 & 1.64 & 7.62 & 4.88 \\
\hline
\end{tabular}

Table 3. Chemical composition of soil conditioners.

\begin{tabular}{cccccc}
\hline $\begin{array}{c}\text { Soil } \\
\text { conditioner }\end{array}$ & $\begin{array}{c}\mathbf{N} \\
(\boldsymbol{\%})\end{array}$ & $\begin{array}{c}\mathbf{P} \\
(\boldsymbol{\%})\end{array}$ & $\begin{array}{c}\mathbf{K} \\
(\boldsymbol{\%})\end{array}$ & $\begin{array}{c}\text { Organic matter } \\
(\boldsymbol{\%})\end{array}$ & $\mathbf{C} / \mathbf{N}$ \\
\hline Compost & 23.8 & 18.6 & 13.3 & 22.6 & 0.136 \\
Rice straw & 0.629 & 1.96 & 0.2 & 1.5 & 0.24 \\
Polymers & 12.1 & 0.03 & 4.6 & & \\
\hline
\end{tabular}

Table 4. Irrigation water chemical analysis in experimental site.

\begin{tabular}{|c|c|c|c|c|c|c|c|c|c|c|c|}
\hline \multirow[t]{2}{*}{ pH } & \multirow{2}{*}{$\begin{array}{c}\text { EC } \\
\left(\text { ds. } \mathbf{m}^{-1}\right)\end{array}$} & \multirow{2}{*}{$\begin{array}{c}\text { TDS } \\
(\mathbf{p p m})\end{array}$} & \multicolumn{4}{|c|}{$\begin{array}{c}\text { Soluble cations } \\
(\mathrm{meq} / \mathrm{l})\end{array}$} & \multicolumn{4}{|c|}{$\begin{array}{c}\text { Soluble anions } \\
(\mathrm{meq} / \mathrm{l})\end{array}$} & \multirow{2}{*}{$\begin{array}{r}\text { SAR } \\
(\%)\end{array}$} \\
\hline & & & $\mathrm{Ca}^{+}$ & $\mathrm{Mg}^{+2}$ & $\mathrm{Na}^{+}$ & $\mathbf{K}^{+}$ & $\mathrm{Co}_{3}{ }^{-2}$ & $\mathrm{HCO}^{-3}$ & $\mathrm{Cl}^{-}$ & $\mathrm{SO}_{4}{ }^{-2}$ & \\
\hline 7 & 7.06 & 4518 & 18.8 & 13.2 & 33 & 0.25 & 0.00 & 2.8 & 46.6 & 15.85 & 8.25 \\
\hline
\end{tabular}




\subsection{Climatic conditions}

Experimental site has a dry climate with cold winter and hot dry summer. The meteorological variables were recorded every day through each of the both growing seasons (2014 and 2015) and they are as follows: the maximum temperature, dew point temperature, minimum relative humidity and wind speed at which were measured at $2 \mathrm{~m}$ above ground (Fig. 1). The total collected depth of rain each year $(<20 \mathrm{~mm})$. Therefore, the presence of soil water is due almost entirely for irrigation.

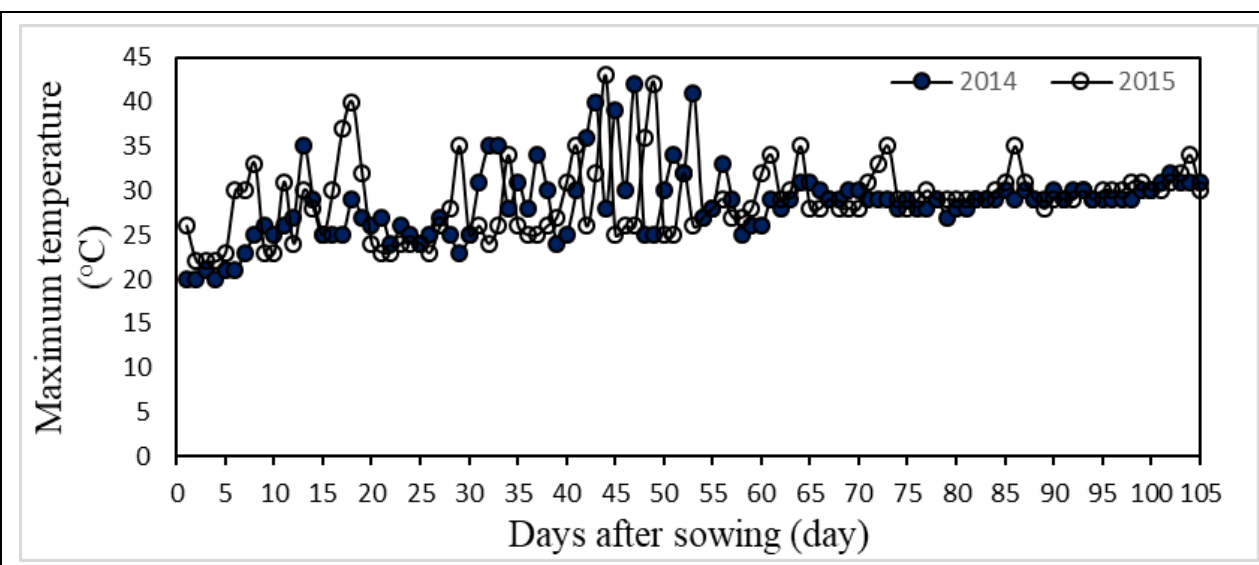

\section{Daily maximum temperature for the two growing seasons}

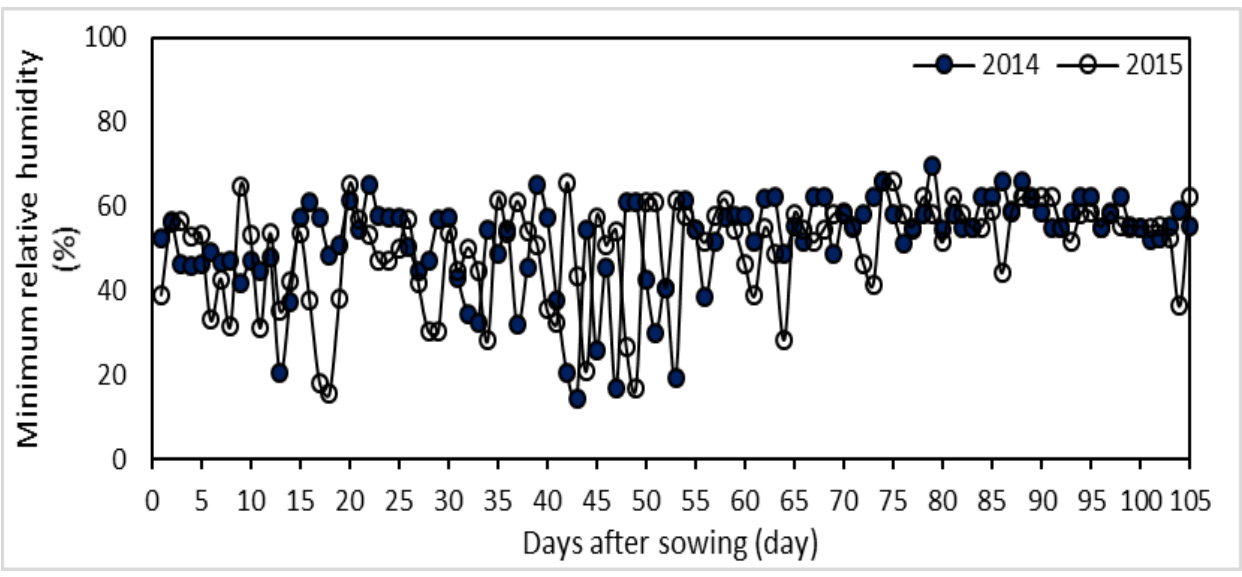

Daily minimum relative humidity for the two growing seasons 


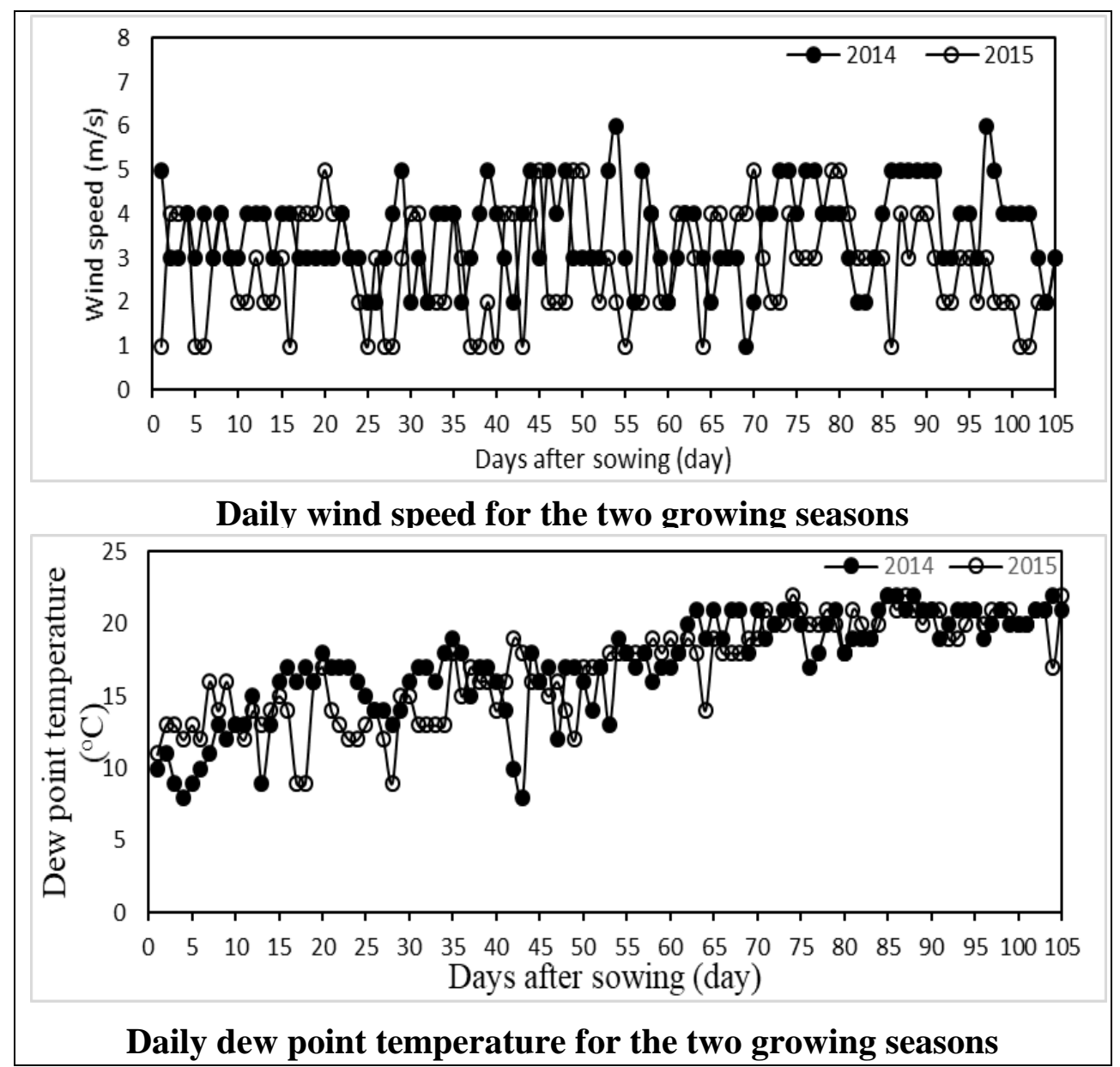

Fig. 1. Daily climatic criteria for both growing seasons of the experimental site.

\subsection{The equilibrium of soil-water and crop evapotranspiration}

Soil-water equilibrium and crop evapotranspiration $\left(\mathrm{ET}_{\mathrm{C}}\right)$ were daily calculated with a computer software written a programming language (Microsoft Excel-Based). The input elements of program were daily weather data including; rainfall depth, irrigation dates and quantities, initial soil moisture content in the soil at crop emergence, crop and experimental site characterization, such as the date of planting, maturity, soil parameters (field capacity, wilting point, available water and management allowable depletion during and after initial stage), the 
maximum depth of the roots. The crop evapotranspiration and soil-water balance in the root zone were daily calculated using the computer program by following the procedures set by the Food and Agriculture Organization 56 (Jose et al., 2008). This procedure calculates the crop evapotranspiration $\left(\mathrm{ET}_{\mathrm{C}}\right)$ using grass as a reference crop to calculate the reference evapotranspiration $\left(\mathrm{ET}_{\mathrm{O}}\right)$ and by multiplying it by crop coefficient $\left(\mathrm{K}_{\mathrm{C}}\right)$ to obtain $\left(\mathrm{ET}_{\mathrm{C}}\right)$.

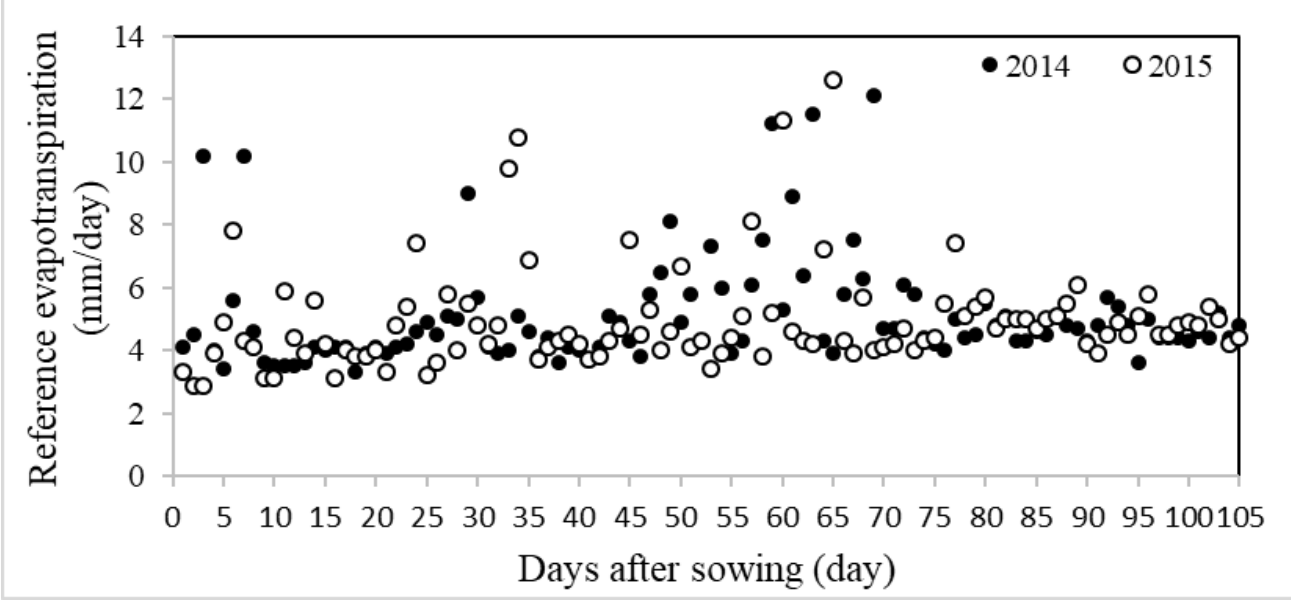

Fig. 2. Daily reference evapotranspiration for both growing seasons of the experimental site.

Reference evapotranspiration is calculated using the weather data as input to the Penman-Monteith equation and the crop coefficient is used to adjust the estimated reference evapotranspiration for grass to that of other crops at different growth stages and growing environments (Figs. 2 and 3).

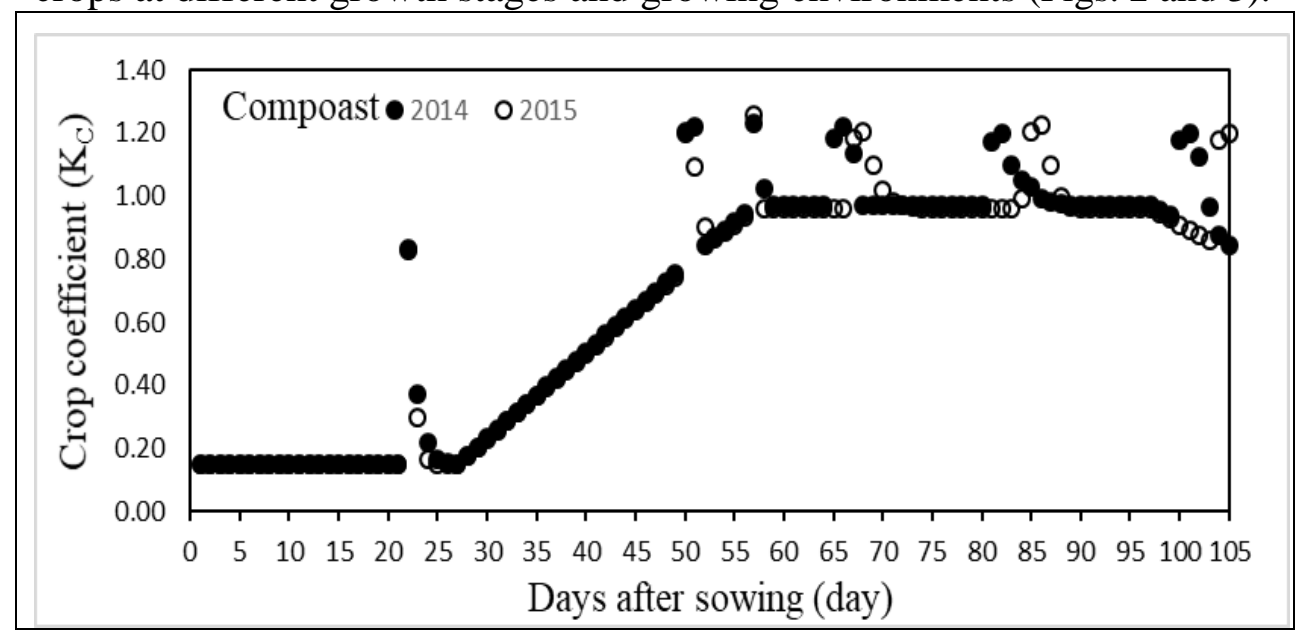




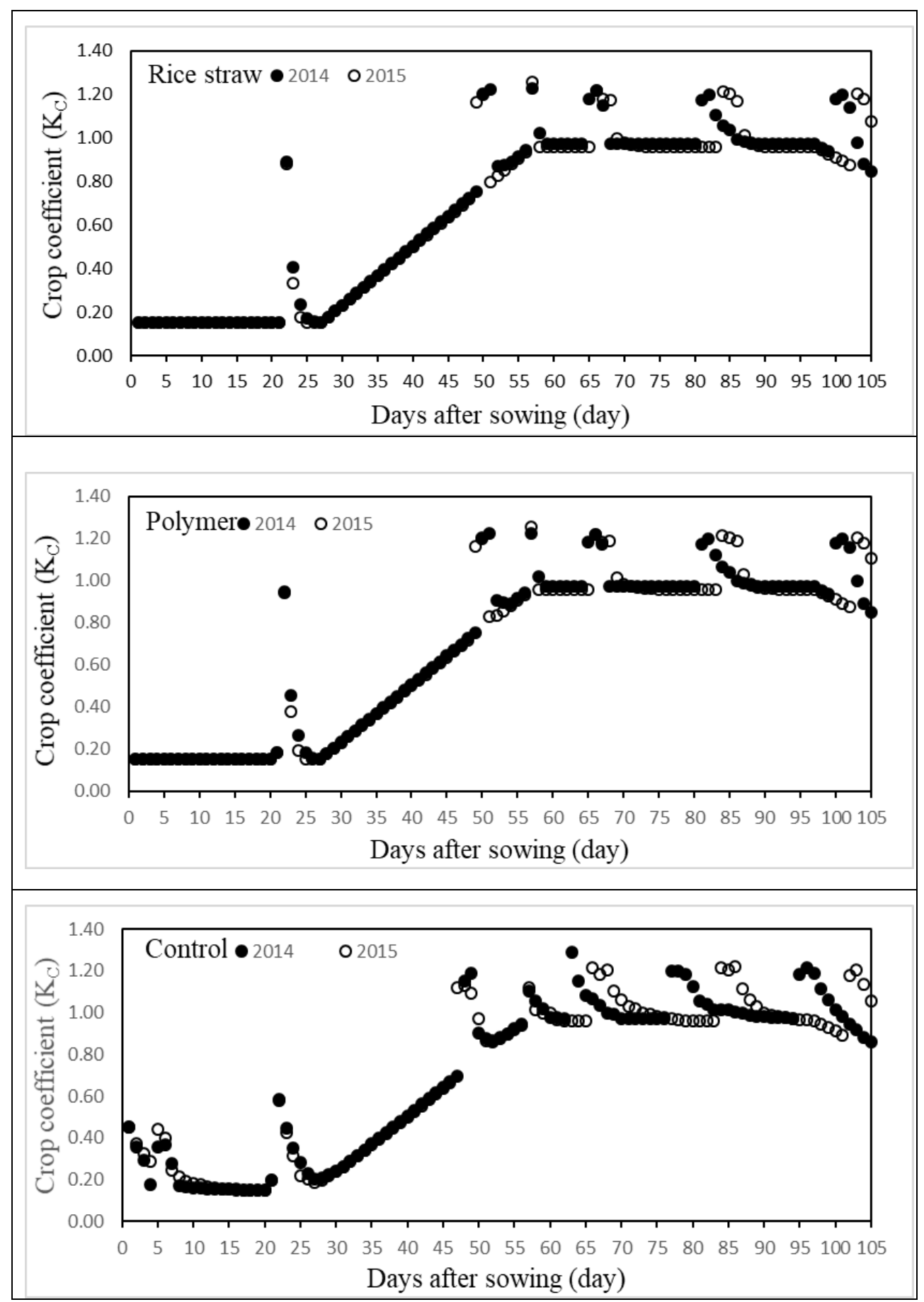

Fig. 3. Crop coefficient under different soil conditioners for both growing seasons. 


\subsection{Soil moisture measurement}

The moisture content in the soil is measured using the soil moisture probe, which has been calibrated using the gravimetric method. Time domain reflectometry (Three-pin bore hole probe + adapter, Eijkelkamp Agriresearch Equipment, Netherland) device consists of a polycarbonate rod $25 \mathrm{~mm}$ diameter, with electronic sensors were placed in pairs in the form of rings of stainless steel and were installed on equal distances on the length of the rod. The soil moisture content was measured at $5 \mathrm{~cm}$ away from the emitter by using TDR. The soil moisture was preserved between field capacity and the refill point which represents $50 \%$ of the total available water in the soil.

This is a common strategy not only for conventional irrigation systems but also for drip irrigation system, especially when applied to sandy soils, arid climate and saline water without any leaching. This strategy has helped to make salts as far as possible from the root zone with help of soil conditioners as a means to overcome the challenges facing the desert areas in Egypt, which suffer from these problems in addition to the growing problem of salinity of groundwater due to over pumping, which resulted in an imbalance between the rate of pumping and the rate of recharge of underground reservoirs in addition to the lack of rain amounts usual fall as a result of climate changes emerged use this strategy with the help of soil conditioners as a solution.

The soil moisture measuring points were $10 \mathrm{~cm}$ apart till $40 \mathrm{~cm}$ depth as a vertical axis and $30 \mathrm{~cm}$ as horizontal axis which represents the distance between plants. The soil moisture measurements were applied before and immediately after irrigation and the data obtained was plotted by Surfer software to see the impact of the use of soil conditioners to improve the soil's capacity to retain water and increase soil moisture content.

\subsection{System installation and experimental treatments}

Field experiment includes three treatments of subsurface drip tapes and four treatments of soil conditioners. Drip tapes treatments were (GR (Eurodrip Egypt, $\mathrm{I}_{1}$ ); GR anti-root (Rain Bird Egypt, $\mathrm{I}_{2}$ ); and T-tape (Eurodrip Egypt, $\left.\mathrm{I}_{3}\right)$ ), while the soil conditioners treatments were (Compost $\left(\mathrm{S}_{1}\right)$; Rice straw $\left(\mathrm{S}_{2}\right)$; Polymer $\left(\mathrm{S}_{3}\right)$; and Control $\left.\left(\mathrm{S}_{4}\right)\right)$, and three 
replicates were adopted for each field treatment. The amounts of applied soil conditioners were; compost (10 ton/fed), rice straw (10 ton/fed), and polymer $(1760 \mathrm{~kg} / \mathrm{fed})$, the soil conditioners were manually added at a depth ranged from $10-20 \mathrm{~cm}$. Irrigation water was applied according to potential evapotranspiration, soil retention information and crop factor during the growing season which was confirmed by soil moisture monitoring.

The irrigation system (Fig. 4) consists of; screen filter 200 mesh, 36 laterals with $15 \mathrm{~m}$ length for each were built-up on an area equal to 0.0432 ha $(15 \mathrm{~m}$ width and

$28.8 \mathrm{~m}$ length) with zero slope. Subsurface laterals were located in a trenches prepared by hand. Bridging the trenches were then carefully using soil that was removed previously. Dripper's lines consists of polyethylene with a diameter of $16 \mathrm{~mm}$, the manifold was $32 \mathrm{~mm}$ diameter PVC pipe.

\subsection{Evaluation of drip tapes}

Hydraulic characteristics experiments were carried out for three types of built-in laterals (GR, GR Anti roots, and T-Tape). 25 emitters were nominated randomly to evaluate the drip tapes by estimating the water application efficiency through dividing the volume of water collected in catch-cans by the estimated time of the experiment. The water application uniformity was calculated through the terminologies of the manufacturer coefficient of variation ( $v$ ) and emission uniformity (EU) by adopting equations (1) and (2) (Keller and Karmeli, 1975) as follows:

$$
\begin{aligned}
& \mathrm{v}=\frac{\mathrm{s}}{\mathrm{q}_{\mathrm{a}}} \\
& \mathrm{EU}=100\left(1.0-1.27 \frac{\mathrm{v}}{\sqrt{\mathrm{N}_{\mathrm{p}}}}\right)
\end{aligned}
$$

where $\mathrm{S}$ is the standard deviation of emitters flowrate (lph); $\mathrm{q}$ the average discharge of tested emitters (lph), $\mathrm{N}_{\mathrm{P}}$ the number of emitters per plant, $\mathrm{q}_{\mathrm{n}}$ the minimum flow rate $(1 / \mathrm{h}), \mathrm{q}_{\mathrm{a}}$ The average flow rate of all emitters (lph) (Table 5). The subsurface drip irrigation system was rated according to the standard classification of the American Society of Agricultural Engineering, which ranges from excellent to unacceptable. (ASAE, 1996a; ASAE, 1996b). 


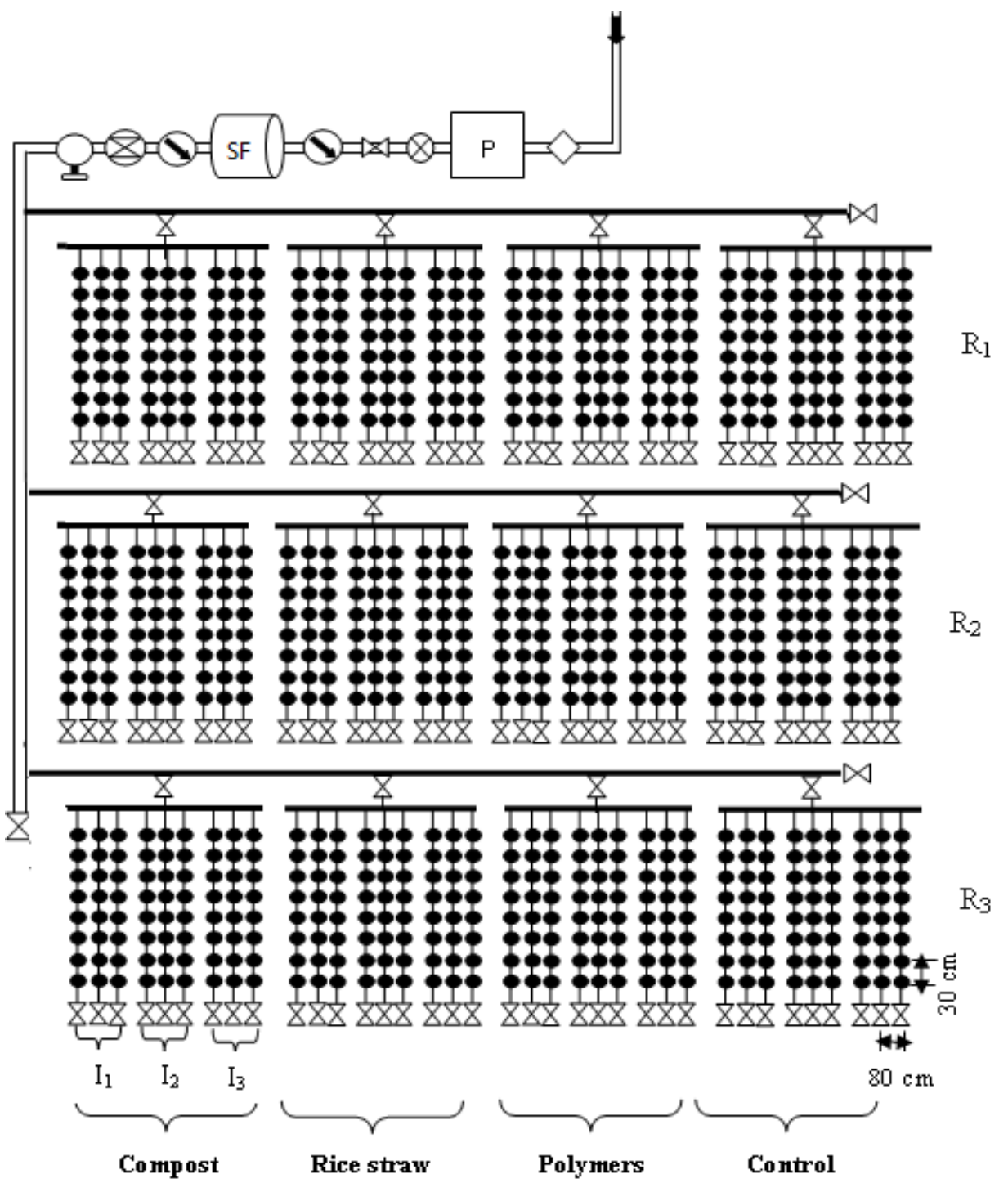

\begin{tabular}{|llllll|}
\hline & & \multicolumn{2}{l|}{ Legend } & & \\
$\otimes$ & Non-return valve & $\bigcirc$ & Pressure Gauge & $\mathbf{p}$ & pump \\
$\otimes$ & Safety valve & $\bigcirc$ & Pressure regulator & $\mathbf{I}_{\mathbf{1}}$ & GR \\
$\boldsymbol{B}$ & Gate valve & $\bigcirc$ & Volume accumulator & $\mathbf{I}_{2}$ & Anti-roots \\
$\otimes$ & Flow meter & $\bullet$ & Emitter & $\mathbf{I}_{3}$ & T-tape \\
SF & Screen filter & & & & \\
\hline
\end{tabular}

Fig. 4. Schematic sketch of micro-irrigation system components and treatments. 
Table 5. Hydraulic properties of lateral drip tapes.

\begin{tabular}{lccc}
\hline \multirow{2}{*}{ Characteristics } & \multicolumn{3}{c}{ Lateral } \\
\cline { 2 - 4 } & GR & $\begin{array}{c}\text { GR } \\
\text { anti-root }\end{array}$ & T-tape \\
\hline Wall thickness (mm) & 1 & 1.2 & 0.3 \\
Internal diameter (mm) & 16 & 16 & 16 \\
Pressure compensating & No & Yes & No \\
Emitter flowrate (lph) & 4 & 4 & 4 \\
Emitter spacing (cm) & 30 & 30 & 30.0 \\
Lateral spacing (cm) & 80 & 80 & 80 \\
Lateral placement depth (cm) & 15.0 & 15.0 & 15.0 \\
Exponent (x) & 0.5 & 0.5 & 0.5 \\
CV & 1.49 & 3.15 & 2.96 \\
EU & 97.1 & 98.8 & 96 \\
\hline
\end{tabular}

\subsection{Data recording}

The final harvest was on 30th of July (105 days after planting (DAP)), 18 plants were harvested from each plot by taking six plants from each of the beginning, middle and end of the plot respectively, to estimate productivity.

Total fresh weight of the fruits was determined ( $\mathrm{kg}$ per plant). The vegetative parameters were plant height, number of branches, number of leaves per plant, fruit diameter, fruit length, fruit weight and fresh weight per plant was derived from final plant harvest. The actual evapotranspiration of cucumber during the growing period was assessed from the soil-water equilibrium through the following equation:

$\mathrm{ET}=\mathrm{I}+\mathrm{P} \pm \Delta \mathrm{SW}-\mathrm{Dp}-\mathrm{R}$

Where ET is the evapotranspiration $(\mathrm{mm})$, I the amount of irrigation water applied $(\mathrm{mm}), \Delta \mathrm{SW}$ the soil water content changes $(\mathrm{mm}), \mathrm{Dp}$ the deep percolation $(\mathrm{mm})$, and $\mathrm{R}$ is the amount of runoff $(\mathrm{mm})$. Since the amount of irrigation water was controlled, and the same saline irrigation water was used for all treatments, and there was no leaching, therefore the buildup of soil salinity would have been very similar, and so the deep percolation and runoff were assumed to be negligible, on the other hand, by this way the effect of using soil conditioners with saline irrigation 
water can be summarized on the yield and water productivity. The water productivity $\left(\mathrm{kg} \mathrm{m}^{-3}\right)$ was computed using Eq. (4) given by Bhushanet al. (2007).

Water productivity $\left(\mathrm{kg} \mathrm{m}^{-3}\right)=$ yield $\left(\mathrm{kg} \mathrm{ha}^{-1}\right) /$ plant water consumption $\left(\mathrm{m}^{3} \mathrm{ha}^{-1}\right)(4)$

\subsection{Statistical analysis}

All measurements in this research were analyzed using the analysis of variance (ANOVA), where it convenient for split plot design in factorial arrangement three factors soil conditioners, laterals hoses and three replicates as blocks. The mean square of a product between the soil conditioners and laterals hoses were used as an error term to test the interaction between each of the factors. The less significant difference (LSD) of Duncan's test has been used to determine the statistical significant differences between average groups in the ANOVA. Classified the probability levels less than 0.05 as significant. All analyses were done by using the MSTAT program (MSTAT is written in the $\mathrm{C}$ programming language and runs on DOS compatible machines).

\section{RESULTS AND DISCUSSIONS}

\subsection{Irrigation and evapotranspiration}

The monthly evapotranspiration and irrigation water applied values calculated in the experiment area using daily weather data. The result show that, there was a decreasing percentage of total evapotranspiration (ET) under soil conditioners treatments of cucumber plant comparing with control by $1.8 \%$, and $1.6 \%$ and $1.24 \%$ under compost $\left(\mathrm{S}_{1}\right)$, rice straw $\left(\mathrm{S}_{2}\right)$, and polymers $\left(\mathrm{S}_{3}\right)$, respectively, for the first season, while it was lower by $1.72 \%, 1.49 \%$ and $1.16 \%$ under $S_{1}, S_{2}$, and $S_{3}$ respectively comparing with control, for the second season. While there was a decreasing percentage of total the irrigation water applied (I) under soil conditioners treatments of cucumber plant comparing with control by $2.92 \%, 2.47 \%$ and $2.29 \%$, under compost $\left(\mathrm{S}_{1}\right)$, rice straw $\left(\mathrm{S}_{2}\right)$, and polymers $\left(\mathrm{S}_{3}\right)$, respectively, for the first season, while it was lower by $2.99 \%, 2.71 \%$, and $2.45 \%$ under $S_{1}, S_{2}$ and $S_{3}$ treatments respectively comparing with control, for the second season (Table 6). 


\subsection{Yield and water productivity}

The yield (the fresh weight of fruits) was $20.12 \%, 34.42 \%$ and $57.31 \%$ higher, in the compost with GR anti-root $\left(\mathrm{I}_{2} \mathrm{~S}_{1}\right)$ comparing with rice straw $\left(\mathrm{I}_{2} \mathrm{~S}_{2}\right)$, polymers $\left(\mathrm{I}_{2} \mathrm{~S}_{3}\right)$, and control $\left(\mathrm{I}_{2} \mathrm{~S}_{4}\right)$ respectively, for the first season (Table 8), while it was higher by $16.7 \%, 32.7$ and $53.8 \%$ than $\left(\mathrm{I}_{2} \mathrm{~S}_{2}\right)$, $\left(\mathrm{I}_{2} \mathrm{~S}_{3}\right)$, and $\left(\mathrm{I}_{2} \mathrm{~S}_{4}\right)$, respectively, for the second season (Table 7).

The water productivity was greater by $10.16 \%$ and $11.8 \%$ under compost with GR anti root $\left(\mathrm{I}_{2} \mathrm{~S}_{1}\right)$ comparing with compost with GR $\left(\mathrm{I}_{1} \mathrm{~S}_{1}\right)$ and compost with t-tape $\left(\mathrm{I}_{3} \mathrm{~S}_{1}\right)$, respectively, for the first season, while it was greater by $8.34 \%$ and $9.5 \%$ than $\left(I_{1} S_{1}\right)$ and $\left(I_{3} S_{1}\right)$, respectively, for the second season.

The results of yield and water productivity agree with Roe et al. (1997), who studied green peppers and cucumbers in a sandy soil fertilized with compost or mineral fertilizers. And they found that, yields were usually higher when compost was combined with mineral fertilizers. Compost treatment gave significantly greater early, exportable and total yield than inorganic (chemical) treatment (Aly, 2002). In this respect, Ali et al. (2006), also found that the application of compost for tomatoes increased water productivity, this could be due to the role of rice straw compost as organic fertilizer on better water holding in the root zone.

The achievement of the highest yield and water productivity under compost treatment was according to that that compost-amended soils exhibited increases in quantity and quality of total organic carbon, nitrogen, phosphorus, microbial biomass, and enzymatic activities (Mylavarapu and Zinati, 2009).

The sequential applications of compost with and without fertilizer increased nutrient uptake and soil nutrient concentrations, soil water retention, and reduced soil bulk density. Obviously compost applications have significant amounts of total carbon and nitrogen, potentially improving the physical and chemical properties of the soils for sustaining optimum crop production (Mylavarapu and Zinati, 2009).

Increased yield was also related to balanced nutrition, better uptake of nutrients by the plants which helped for better fruit set and fruit yield. More yield of cucumber in present study could be due to the influence of bio-fertilizers in combination with N-P-K and FYM enhanced the 
synthesis of photosynthetic by increasing the synthesis of growth regulators.

The lower yield and so water productivity under polymer treatment was related to that most polymeric super absorbents are based on sodium poly acrylate, but they are not suitable for saline water and soils (Akelah, 2013).

The control treatment had the lowest values of soil nutrients, growth and yield parameters of cucumber when compared to other treatments this is related to the saline irrigation water. The result was also supported by (Moyin-Jesu and Ojeniyi, 2006).

\subsection{Soil moisture content}

The distribution of water through soil profile of sandy soil under subsurface trickle irrigation system is regarded as one of the most significant factor for good soil water management.

Compost has uniformity in soil moisture content the maximum soil moisture content values before and after irrigation were detected at depth ranged from $10-30 \mathrm{~cm}$ and it was $11 \%$, and $21 \%$ before and after irrigation respectively, and gradually decreased up and down till the minimum values at soil surface were $3 \%$, and $5 \%$ before and after irrigation respectively, and $6.5 \%$, and $17 \%$ before and after irrigation respectively, at $40 \mathrm{~cm}$ depth (Fig. 5).

The soil moisture content for rice straw, it turned out that there were high and low moisture content spots, the great moisture content was detected at layer ranged from $15-35 \mathrm{~cm}$ before and after irrigation, and it were 6\% and $18 \%$ before and after irrigation respectively, and gradually decreased up and down, till the lowest values at soil surface was $2.5 \%$, and $4 \%$ before and after irrigation respectively, and 5\%, and $12 \%$ before and after irrigation respectively, at $40 \mathrm{~cm}$ depth. According to the high permeability of rice straw the water infiltrate downward fast (Fig. 6).

The polymer treatment achieved the highest soil moisture content with $24 \%$ after irrigation, and it was detected at depth ranged from $10-25 \mathrm{~cm}$ and it gradually decreased in the two direction up and down till the lowest soil moisture content $3 \%$ at soil surface and $5 \%$ at $40 \mathrm{~cm}$ depth, the depth ranged from $10-25 \mathrm{~cm}$ already reached to field capacity $21 \%$ for the sandy soil with polymers (Fig. 7). 
Table 6. Monthly water applied for each soil conditioner treatment under growing seasons.

\begin{tabular}{|c|c|c|c|c|c|c|c|c|c|c|c|}
\hline \multirow[b]{2}{*}{ Year } & \multirow{2}{*}{$\begin{array}{l}\text { Soil } \\
\text { cond. }\end{array}$} & \multicolumn{2}{|c|}{ April } & \multicolumn{2}{|c|}{ May } & \multicolumn{2}{|c|}{ June } & \multicolumn{2}{|c|}{ July } & \multicolumn{2}{|c|}{ Total } \\
\hline & & $\begin{array}{c}\text { ET } \\
\left(\mathrm{m}^{3} \mathbf{h a}^{-1}\right)\end{array}$ & $\begin{array}{c}\text { I } \\
\left(\mathrm{m}^{3} \mathrm{ha}^{-1}\right)\end{array}$ & $\begin{array}{c}\text { ET } \\
\left(\mathbf{m}^{3} \mathbf{h a}^{-1}\right)\end{array}$ & $\begin{array}{c}\text { I } \\
\left(\mathrm{m}^{3} \mathrm{ha}^{-1}\right)\end{array}$ & $\begin{array}{c}\text { ET } \\
\left(\mathbf{m}^{3} \mathbf{h a}^{-1}\right)\end{array}$ & $\begin{array}{c}\text { I } \\
\left(\mathrm{m}^{3} \mathbf{h a}^{-1}\right)\end{array}$ & $\begin{array}{c}\text { ET } \\
\left(\mathbf{m}^{3} \mathbf{h a}^{-1}\right)\end{array}$ & $\begin{array}{c}\text { I } \\
\left(\mathrm{m}^{3} \mathrm{ha}^{-1}\right)\end{array}$ & $\begin{array}{c}\text { ET } \\
\left(\mathrm{m}^{3} \mathbf{h a}^{-1}\right)\end{array}$ & $\begin{array}{c}\text { I } \\
\left(\mathrm{m}^{3} \mathbf{h a}^{-1}\right)\end{array}$ \\
\hline \multirow[t]{4}{*}{2014} & Com. & 818 & 1072 & 900 & 1220 & 897 & 1647 & 877 & 950 & 3492 & 4889 \\
\hline & R.S. & 823 & 1078 & 901 & 1222 & 898 & 1649 & 878 & 963 & 3500 & 4912 \\
\hline & Pol. & 831 & 1080 & 903 & 1225 & 900 & 1652 & 880 & 964 & 3513 & 4921 \\
\hline & Cont. & 799 & 1109.1 & 988 & 1252.7 & 891 & 1698.4 & 879 & 976.13 & 3557 & 5036.3 \\
\hline \multirow[t]{4}{*}{2015} & Com. & 815 & 1014 & 897 & 1138 & 870 & 1558 & 901 & 947 & 3484 & 4657 \\
\hline & R.S. & 826 & 1017.6 & 894 & 1140.9 & 870 & 1563.2 & 902 & 948.8 & 3492 & 4670.5 \\
\hline & Pol. & 834 & 1020.3 & 896 & 1142 & 872 & 1567 & 904 & 952 & 3504 & 4681.3 \\
\hline & Cont. & 805 & 1051 & 984 & 1166.1 & 881 & 1603.0 & 876 & 980.7 & 3545 & 4800.8 \\
\hline
\end{tabular}


Table 7. The characteristics of water productivity and yield of cucumber for different lateral drip tapes and soil conditioners and the interactions between them for both growing seasons.

\begin{tabular}{|c|c|c|c|c|c|}
\hline Year & Treatments & $\underset{\left(m^{3} h^{-1}\right)}{I}$ & $\begin{array}{c}\text { ET } \\
\left(\mathrm{m}^{3} h^{-1}\right)\end{array}$ & $\begin{array}{c}\text { Yield } \\
\left(t h^{-1}\right)\end{array}$ & $\begin{array}{l}\text { Water productivity } \\
\qquad\left(\mathrm{kg} \mathrm{m}^{-3}\right)\end{array}$ \\
\hline \multirow[t]{22}{*}{2014} & $\mathrm{I}_{1}$ & 4939.58 & 4150 & $19.66 b$ & $4.76 b$ \\
\hline & $\mathrm{I}_{2}$ & 4939.58 & 4150 & $20.653 a$ & $4.99 a$ \\
\hline & $\mathrm{I}_{3}$ & 4939.58 & 4150 & $18.631 \mathrm{c}$ & $4.45 c$ \\
\hline & LSD & NS & NS & 0.28 & 0.036 \\
\hline & $\mathrm{S}_{1}$ & 4889 & 4093 & $27.82 \mathrm{a}$ & $6.79 a$ \\
\hline & $\mathrm{S}_{2}$ & 4912 & 4104.2 & $19.69 b$ & $4.79 b$ \\
\hline & $\mathrm{S}_{3}$ & 4921 & 4120.9 & $17.77 \mathrm{c}$ & $4.3 c$ \\
\hline & $\mathrm{S}_{4}$ & 5036.3 & 4283.0 & $12.96 \mathrm{~d}$ & $3.01 \mathrm{~d}$ \\
\hline & LSD & NS & $\mathrm{Ns}$ & 0.3 & 0.04 \\
\hline & $\mathrm{I}_{1} \mathrm{~S}_{1}$ & 4889 & 4093 & $27.22 b$ & $6.65 b$ \\
\hline & $\mathrm{I}_{1} \mathrm{~S}_{2}$ & 4912 & 4104 & $19.57 \mathrm{e}$ & $4.769 \mathrm{e}$ \\
\hline & $\mathrm{I}_{1} \mathrm{~S}_{3}$ & 4921 & 4120 & $18.46 \mathrm{~h}$ & $4.481 \mathrm{f}$ \\
\hline & $\mathrm{I}_{1} \mathrm{~S}_{4}$ & 5036.3 & 4283 & $13.4 \mathrm{f}$ & $3.129 \mathrm{i}$ \\
\hline & $\mathrm{I}_{2} \mathrm{~S}_{1}$ & 4889 & 4093 & $30.33 a$ & $7.41 \mathrm{a}$ \\
\hline & $\mathrm{I}_{2} \mathrm{~S}_{2}$ & 4912 & 4104 & $20.16 d$ & $4.912 \mathrm{~d}$ \\
\hline & $\mathrm{I}_{2} \mathrm{~S}_{3}$ & 4921 & 4120 & $18.27 f$ & $4.434 \mathrm{f}$ \\
\hline & $\mathrm{I}_{2} \mathrm{~S}_{4}$ & 5036.3 & 4283 & $13.85 \mathrm{~h}$ & $3.234 \mathrm{~h}$ \\
\hline & $\mathrm{I}_{3} \mathrm{~S}_{1}$ & 4889 & 4093 & $25.92 \mathrm{c}$ & $6.333 c$ \\
\hline & $\mathrm{I}_{3} \mathrm{~S}_{2}$ & 4912 & 4104 & $19.35 \mathrm{e}$ & $4.715 \mathrm{e}$ \\
\hline & $\mathrm{I}_{3} \mathrm{~S}_{3}$ & 4921 & 4120 & $16.57 \mathrm{~g}$ & $4.022 \mathrm{~g}$ \\
\hline & $\mathrm{I}_{3} \mathrm{~S}_{4}$ & 5036.3 & 4283 & $11.62 \mathrm{i}$ & $2.713 \mathrm{j}$ \\
\hline & LSD & NS & NS & 0.5 & 0.08 \\
\hline \multirow[t]{12}{*}{2015} & $\mathrm{I}_{1}$ & 4702.4 & 3950.8 & $20.07 b$ & $5.11 b$ \\
\hline & $\mathrm{I}_{2}$ & 4702.4 & 3950.8 & $21.49 \mathrm{a}$ & $5.55 \mathrm{a}$ \\
\hline & $\mathrm{I}_{3}$ & 4702.4 & 3950.8 & $18.1 \mathrm{c}$ & $4.61 \mathrm{c}$ \\
\hline & LSD & NS & NS & 0.2 & 0.19 \\
\hline & $\mathrm{S}_{1}$ & 4657 & 3889.3 & $27.93 \mathrm{a}$ & 7.18a \\
\hline & $\mathrm{S}_{2}$ & 4670.5 & 3904 & $20.45 b$ & $4.24 \mathrm{c}$ \\
\hline & $\mathrm{S}_{3}$ & 4681.3 & 3926 & $18.45 c$ & $4.7 b$ \\
\hline & $\mathrm{S}_{4}$ & 4800.8 & 4083.9 & $12.7 \mathrm{~d}$ & $3.2 \mathrm{~d}$ \\
\hline & LSD & NS & NS & 0.3 & 0.17 \\
\hline & $\mathrm{I}_{1} \mathrm{~S}_{1}$ & 4657 & 3889.3 & $27.486 b$ & $7.067 \mathrm{~b}$ \\
\hline & $\mathrm{I}_{1} \mathrm{~S}_{2}$ & 4670.5 & 3904 & $20.944 d$ & $5.365 d$ \\
\hline & $\mathrm{I}_{1} \mathrm{~S}_{3}$ & 4681.3 & 3926 & $18.618 \mathrm{~g}$ & $4.742 \mathrm{e}$ \\
\hline
\end{tabular}




$\begin{array}{ccccc}\mathrm{I}_{1} \mathrm{~S}_{4} & 4800.8 & 4083.9 & 13.245 \mathrm{j} & 3.243 \mathrm{~h} \\ \mathrm{I}_{2} \mathrm{~S}_{1} & 4657 & 3889.3 & 30.505 \mathrm{a} & 7.843 \mathrm{a} \\ \mathrm{I}_{2} \mathrm{~S}_{2} & 4670.5 & 3904 & 21.029 \mathrm{~d} & 5.387 \mathrm{~d} \\ \mathrm{I}_{2} \mathrm{~S}_{3} & 4681.3 & 3926 & 20.738 \mathrm{e} & 5.282 \mathrm{~d} \\ \mathrm{I}_{2} \mathrm{~S}_{4} & 4800.8 & 4083.9 & 13.704 \mathrm{i} & 3.356 \mathrm{~g} \\ \mathrm{I}_{3} \mathrm{~S}_{1} & 4657 & 3889.3 & 25.821 \mathrm{c} & 6.639 \mathrm{c} \\ \mathrm{I}_{3} \mathrm{~S}_{2} & 4670.5 & 3904 & 19.394 \mathrm{f} & 4.968 \mathrm{e} \\ \mathrm{I}_{3} \mathrm{~S}_{3} & 4681.3 & 3926 & 16.047 \mathrm{~h} & 4.087 \mathrm{f} \\ \mathrm{I}_{3} \mathrm{~S}_{4} & 4800.8 & 4083.9 & 11.16 \mathrm{k} & 2.733 \mathrm{i} \\ \text { LSD } & \mathrm{NS} & \mathrm{NS} & 0.13 & 0.29\end{array}$

Note: Numbers followed by different letters within the growing season are statistically different $(\mathrm{P} \leq 0.05)$.

The maximum soil moisture content values before and after irrigation under control treatment were detected at depth ranged from $10-25 \mathrm{~cm}$ and it was $6.6 \%$, and $12 \%$ before and after irrigation respectively, and gradually decreased up and down till the minimum values at soil surface were $3.8 \%$, and $5 \%$ before and after irrigation respectively, and 5\%, and $8.7 \%$ before and after irrigation respectively, at $40 \mathrm{~cm}$ depth (Fig. 8).

The result showed that the water front distribution for rice straw and control treatments was moved downward faster with depth than the polymers and compost treatments under different drip tapes types. On the other hand, El-Berry et al. (1989), pointed out that in subsurface trickle, the minimum moisture content was observed in the upper layer $(0-5 \mathrm{~cm})$ before and after irrigation where it was (2.4\%), the moisture percentage increased with depth to reach its maximum value at a depth of $22 \mathrm{~cm}$ below the lateral in sandy soil.

The application of polymer to the soil increases the water available for the plant. Available moisture content has increased in the soil for plant under polymer treatment, it can be in accordance with the structure of the polymer and hydrophilic properties of the polymer. The pore size distribution and soil capillary are of the factors that affecting on soil water retention capacity and accordingly soil moisture content under suction application. Super absorbent polymer has hydrophilic properties, leading to the creation of changes in soil properties such as increased soil moisture content, porosity and small capillary effect (Shahrokhian et al., 2013). 


\section{Before irrigation}

A

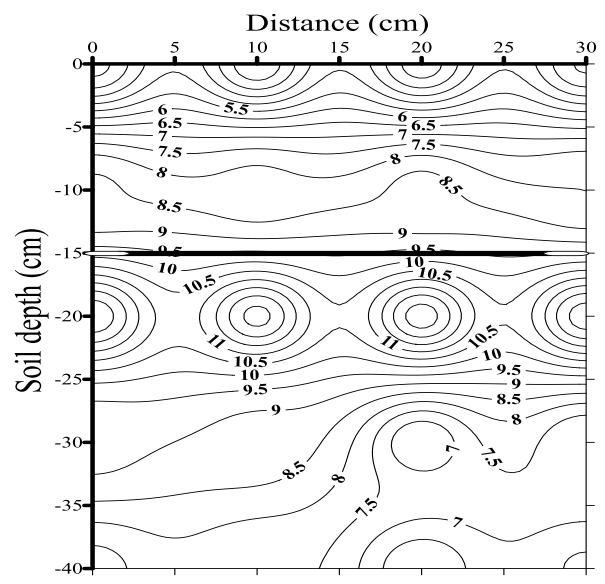

B

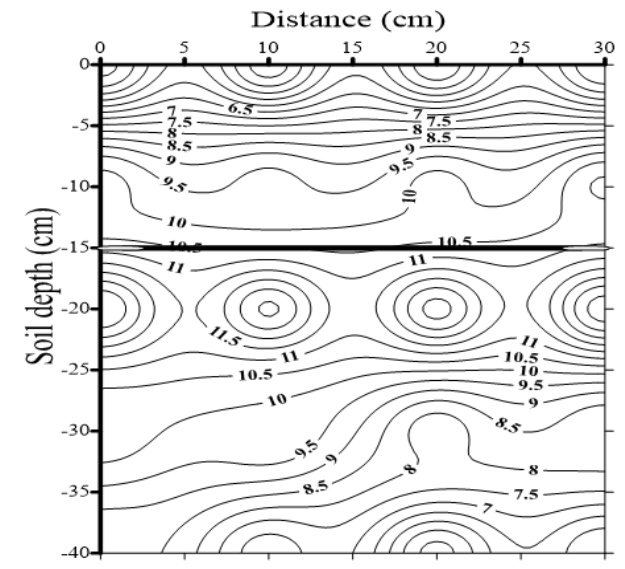

C

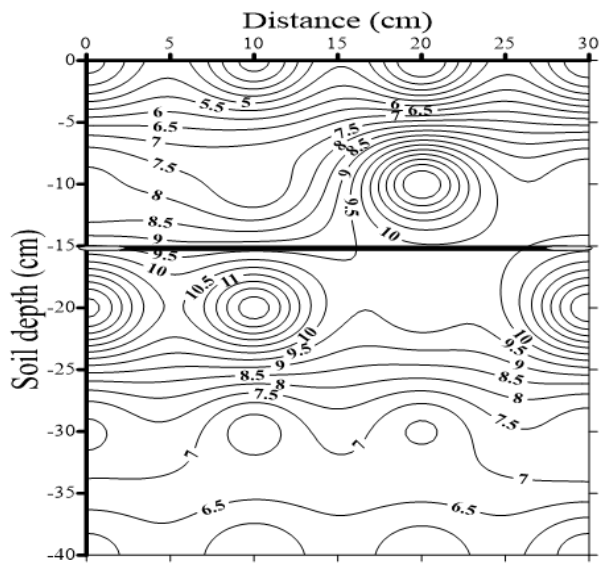

\section{After irrigation}

A

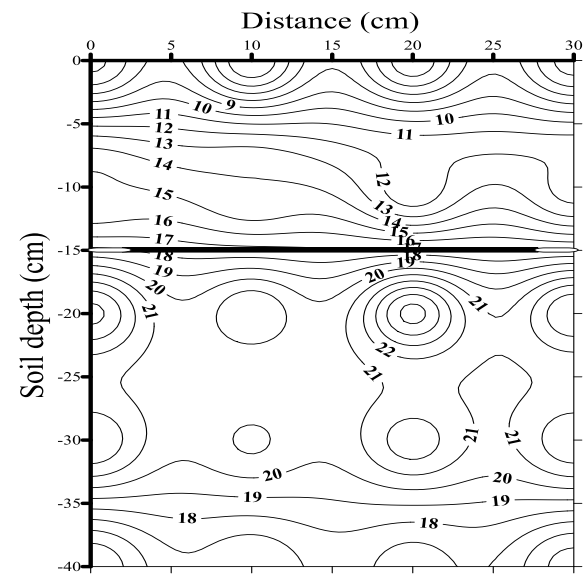

B

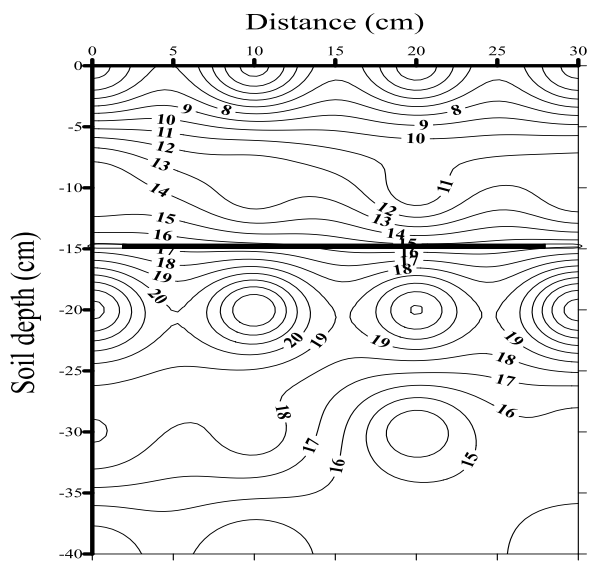

C

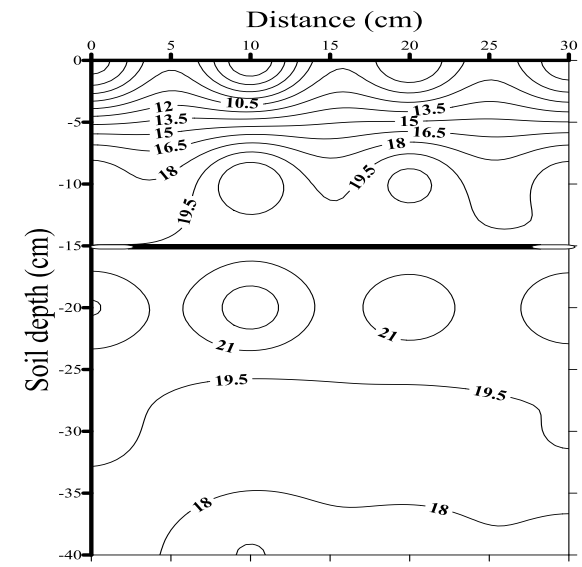

Fig. 5. Soil moisture distribution under compost for different drip tapes (A: GR, B: GR anti-root and C: T-tape). 


\section{Before irrigation}

A

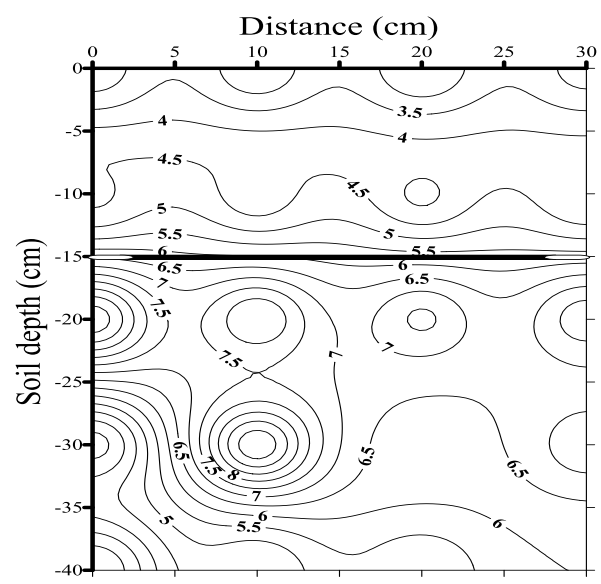

B

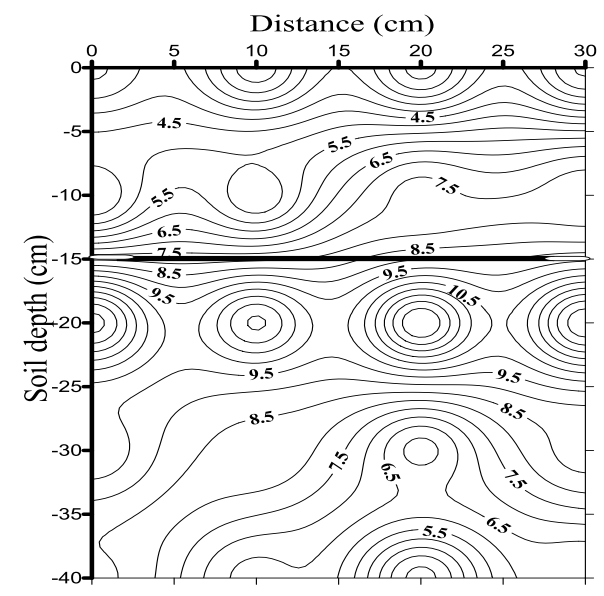

C

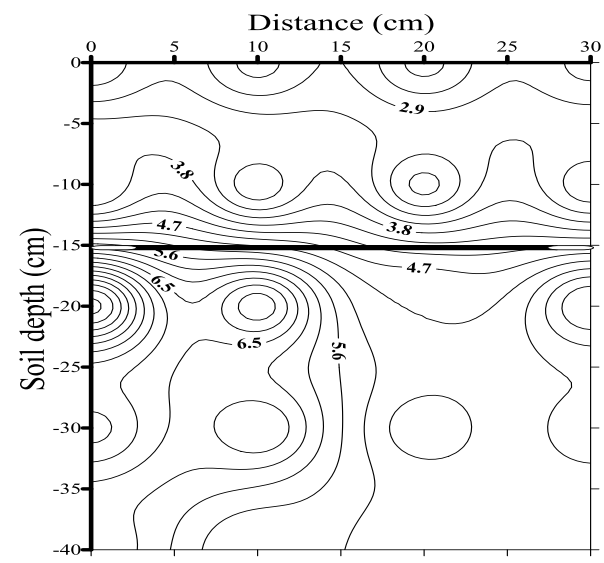

After irrigation

A

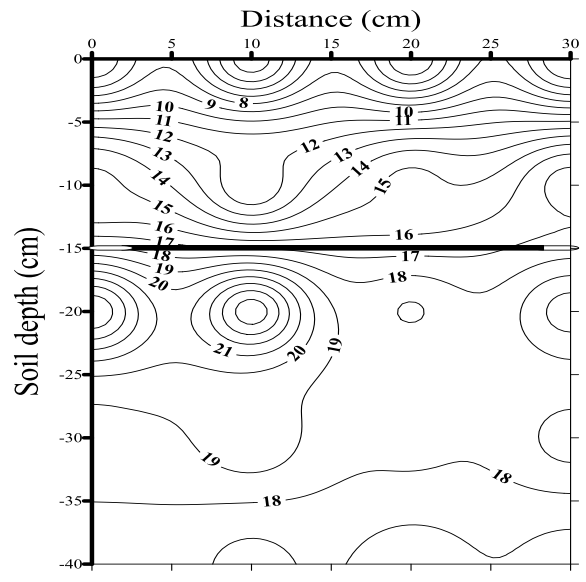

B

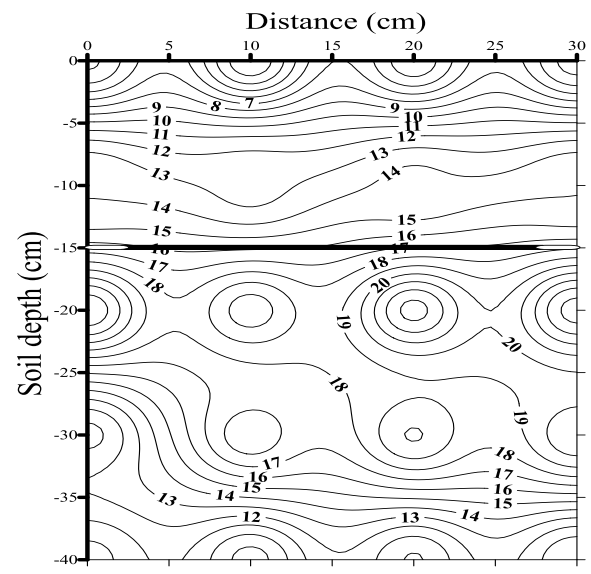

C

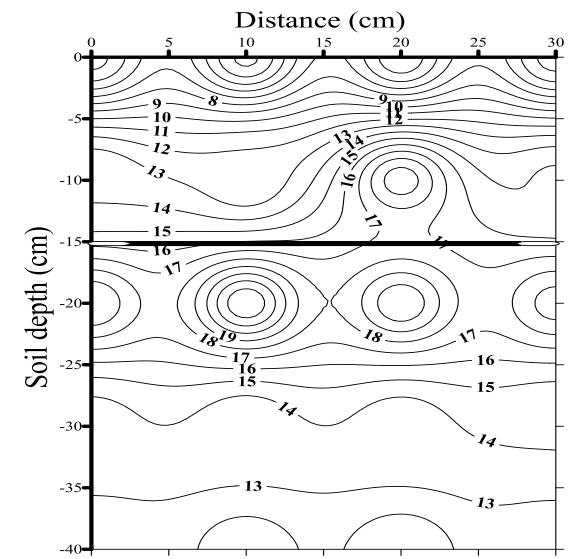

Fig. 6. Soil moisture distribution under rice straw for different drip tapes (A: GR, B: GR anti-root and C: T-tape). 
Before irrigation

A

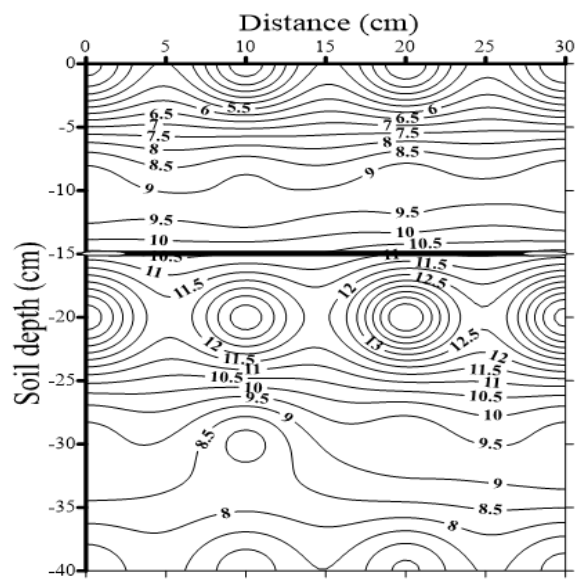

B

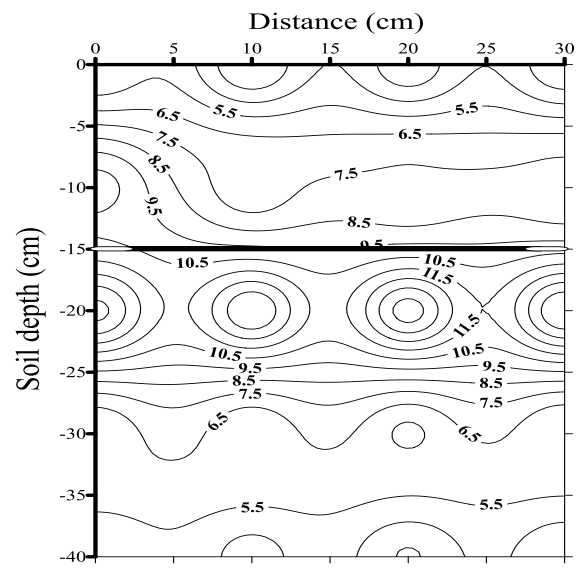

C

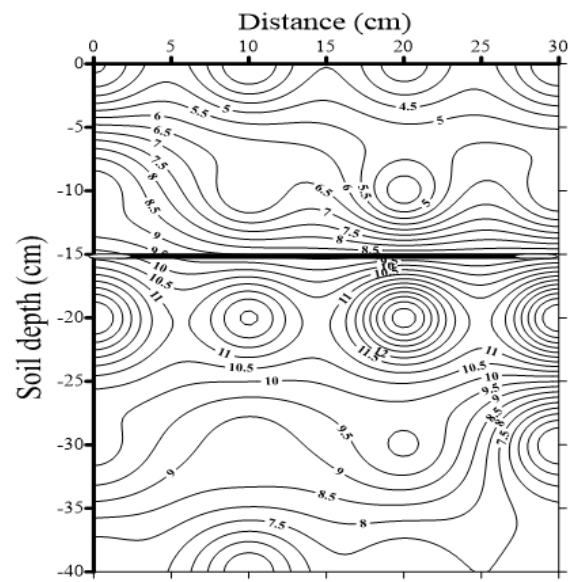

\section{After irrigation}

A

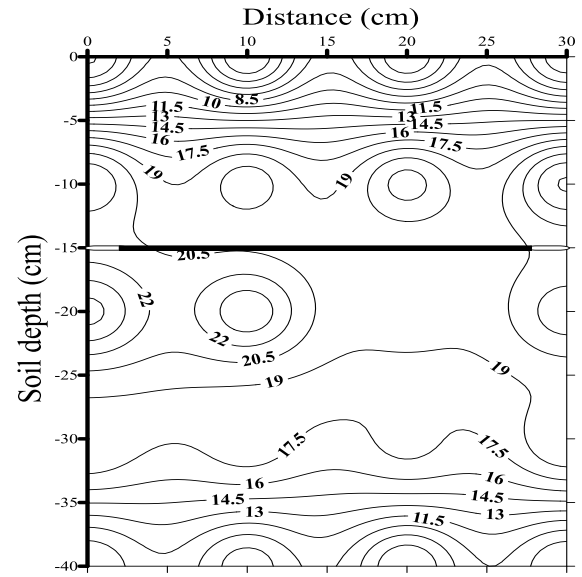

B

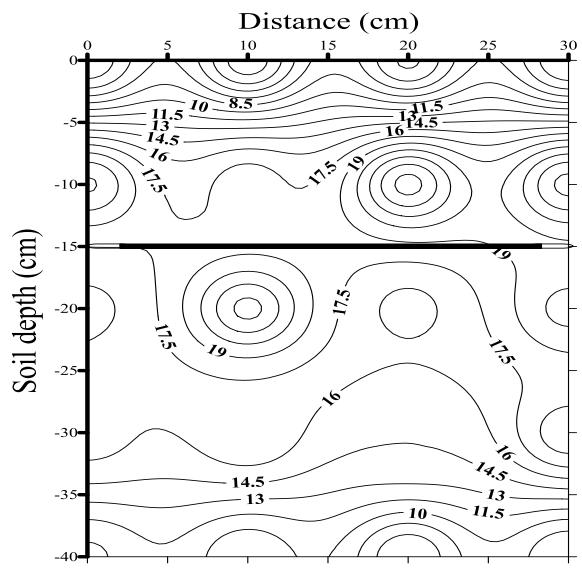

C

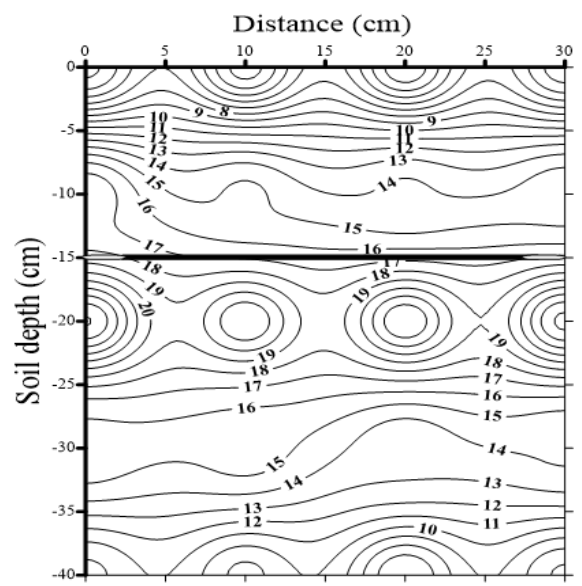

Fig. 7. Soil moisture distribution under polymer for different drip tapes (A: GR, B: GR anti-root and C: T-tape). 
Before irrigation

A

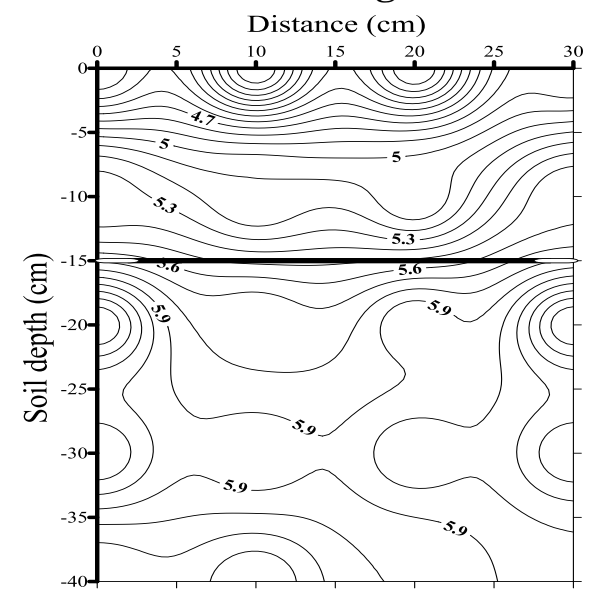

B

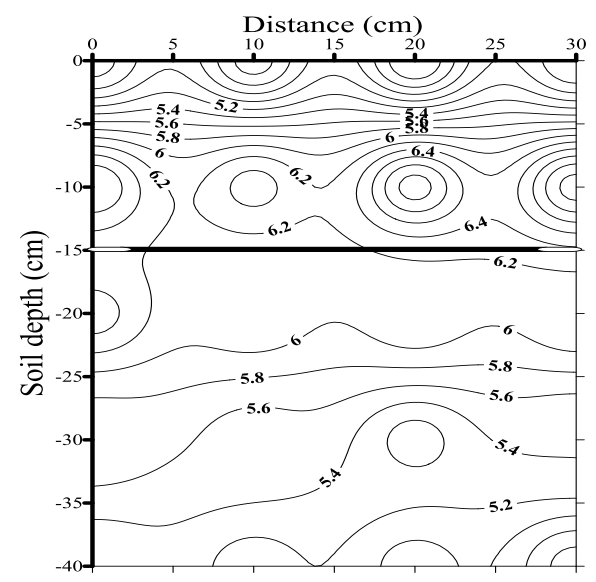

C

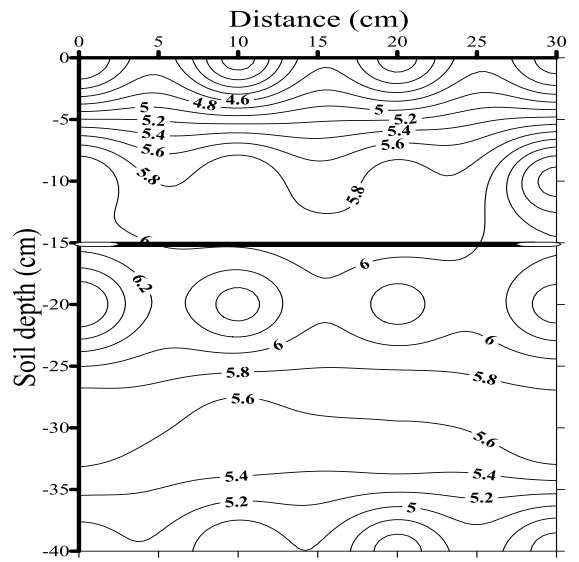

After irrigation

A

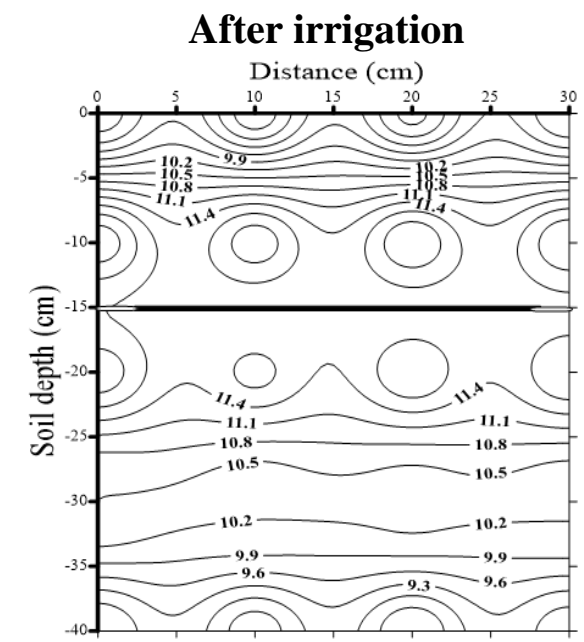

B

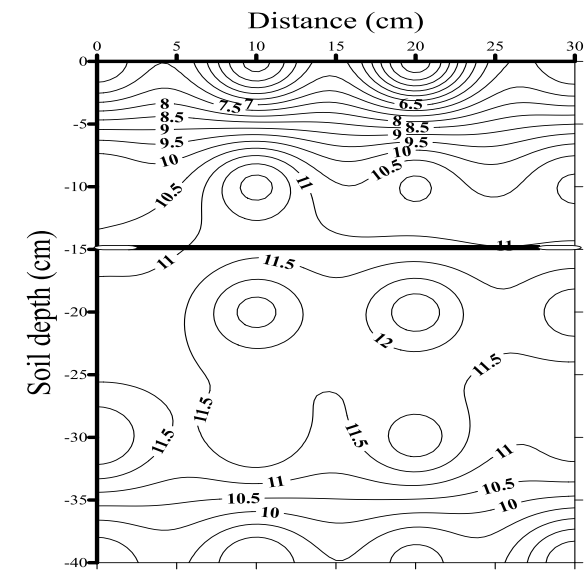

C

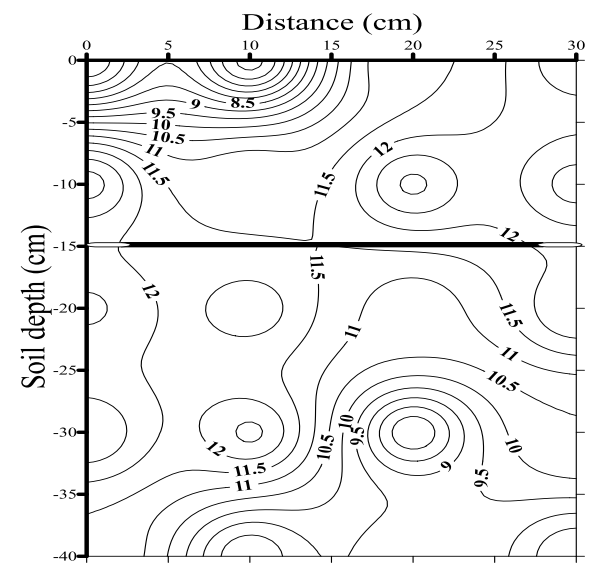

Fig. 8. Soil moisture distribution under control for different drip tapes (A: GR, B: GR anti-root and C: T-tape). 


\subsection{Vegetative growth parameters}

The growth characteristics of cucumber showed a significant difference between the three soil conditioners $\left(S_{1}, S_{2}\right.$, and $\left.S_{3}\right)$ for the two growing seasons, furthermore, there were significant differences between drip tapes treatments $\left(I_{1}, I_{2}\right.$ and $\left.I_{3}\right)$ for plant height, number of branches, number of leaves and fruit weight, while for the rest of vegetative parameter there is no significant difference. The interaction between soil conditioners and irrigation drip tapes treatments most of vegetative parameters were significant differences except number of branches, Fruit length, and Fruit diameter for both growing seasons (Table 8).

Plant height is not a productivity indicator in the vegetables, but it illustrates the effect of different nutrients on metabolism. There were significant differences in plant height between lateral drip types, soil conditioners, and the interactions between them for both growing seasons. For drip types treatments there was $5.5 \%$, and $4.5 \%$ increase in plant height under GR anti-roots comparing with GR and T-tape for the first season, and $4.7 \%$, and $8.1 \%$ in plant height under GR anti-roots comparing with GR and T-tape in the second season. For soil conditioners, there was $8.8 \%, 16.1 \%$, and $33.5 \%$ increase in plant height of cucumber under compost comparing with rice straw, polymer, and control (without soil conditioner) for the first season, while there was $8.5 \%, 18.6 \%$, and $29.1 \%$ increase in plant height of cucumber under compost comparing with rice straw, polymers, and control treatments for the second season. For the interaction between the lateral drip types and soil conditioners, the maximum value of plant height was $(166.3 \mathrm{~cm})$ under compost with anti-roots treatment $\left(\mathrm{I}_{2} \mathrm{~S}_{1}\right)$, while the minimum value was $(102 \mathrm{~cm})$ under control with $\mathrm{GR}\left(\mathrm{I}_{1} \mathrm{~S}_{4}\right)$, for the first season, and the maximum value of plant height was $(162 \mathrm{~cm})$ under compost with GR anti-roots treatment, while the lowest value was $(104 \mathrm{~cm})$ under control with T-tape, for the second season (Table 8).

For the first season, there was a significant difference of number of branches between lateral drip tapes, and between soil conditioners, while there was no significant difference between the interactions between them. For the second season there was significant difference between soil conditioners and there is no significant difference between lateral drip 
tapes and interaction between them. With respect to vegetative parameters, the number of branches had the highest values (22.66) under compost with t-tape $\left(\mathrm{I}_{3} \mathrm{~S}_{1}\right)$, while the lowest value was (11.0) and it was recorded under polymer with GR anti-roots $\left(\mathrm{I}_{2} \mathrm{~S}_{3}\right)$, for the first season, while the highest values of number of branches was (22.60) under $\left(\mathrm{I}_{3} \mathrm{~S}_{1}\right)$, while the lowest value was (11.33) was recorded under $\left(\mathrm{I}_{2} \mathrm{~S}_{3}\right)$, for the second season.

Table 8. Vegetative growth parameters of cucumber in different years and treatments.

\begin{tabular}{|c|c|c|c|c|c|c|c|c|}
\hline year & Treatment & $\begin{array}{l}\text { Plant } \\
\text { height } \\
(\mathrm{cm})\end{array}$ & $\begin{array}{c}\text { No. of } \\
\text { branches }\end{array}$ & $\begin{array}{l}\text { No. of } \\
\text { leaves }\end{array}$ & $\begin{array}{c}\text { Leaves } \\
\text { area } \\
\left(\mathrm{cm}^{2}\right)\end{array}$ & $\begin{array}{c}\text { Fruit } \\
\text { length } \\
(\mathrm{cm})\end{array}$ & $\begin{array}{c}\text { Fruit } \\
\text { diameter } \\
\text { (cm) }\end{array}$ & $\begin{array}{c}\text { Fruit } \\
\text { weight } \\
\text { (g) }\end{array}$ \\
\hline \multirow[t]{22}{*}{2014} & $\mathrm{I}_{1}$ & $133.61 b$ & $14.58 b$ & $24.02 \mathrm{~b}$ & 157.70 & 16.03 & 2.57 & $98.76 b$ \\
\hline & $\mathrm{I}_{2}$ & $141.33 \mathrm{a}$ & $15.16 \mathrm{~b}$ & $26.16 \mathrm{a}$ & 161.61 & 16.58 & 2.69 & $120.71 \mathrm{a}$ \\
\hline & $\mathrm{I}_{3}$ & $134.92 b$ & $17.58 \mathrm{a}$ & $23.56 \mathrm{~b}$ & 155.46 & 15.83 & 2.48 & $117.00 \mathrm{a}$ \\
\hline & LSD & 1.646 & 1.86 & 0.62 & NS & NS & NS & 16.53 \\
\hline & $\mathrm{S}_{1}$ & $160.02 \mathrm{a}$ & $21.11 \mathrm{a}$ & $30.67 \mathrm{a}$ & $193.67 a$ & $17.20 \mathrm{a}$ & $2.87 \mathrm{a}$ & $128.97 \mathrm{a}$ \\
\hline & $\mathrm{S}_{2}$ & $145.89 \mathrm{~b}$ & $16.00 \mathrm{~b}$ & $23.8 \mathrm{c}$ & $173.36 \mathrm{~b}$ & $16.90 \mathrm{a}$ & $2.60 \mathrm{~b}$ & $113.80 \mathrm{ab}$ \\
\hline & $\mathrm{S}_{3}$ & $134.21 \mathrm{c}$ & $12.11 \mathrm{c}$ & $26.61 b$ & $155.95 \mathrm{c}$ & $14.82 \mathrm{~b}$ & $2.39 \mathrm{c}$ & $105.48 b$ \\
\hline & $\mathrm{S}_{4}$ & $106.35 d$ & $13.88 \mathrm{bc}$ & $17.25 \mathrm{~d}$ & $110.04 d$ & $15.67 \mathrm{c}$ & $2.45 b c$ & $100.38 b$ \\
\hline & LSD & 1.78 & 3.07 & 1.05 & 4.21 & 0.71 & 0.16 & 19.59 \\
\hline & $\mathrm{I}_{1} \mathrm{~S}_{1}$ & $156.45 \mathrm{bc}$ & 20.66 & $30.5 b$ & 192.67 & 16.76 & 2.81 & 116.76 \\
\hline & $\mathrm{I}_{1} \mathrm{~S}_{2}$ & $143.97 \mathrm{~d}$ & 14.33 & $24 \mathrm{fg}$ & 178.26 & 16.60 & 2.68 & 93.70 \\
\hline & $\mathrm{I}_{1} \mathrm{~S}_{3}$ & $131.17 f$ & 11.00 & 26.4de & 148.43 & 14.96 & 2.36 & 91.80 \\
\hline & $\mathrm{I}_{1} \mathrm{~S}_{4}$ & $102.83 \mathrm{~h}$ & 12.33 & $15.25 \mathrm{i}$ & 111.33 & 15.80 & 2.44 & 92.80 \\
\hline & $\mathrm{I}_{2} \mathrm{~S}_{1}$ & $166.29 a$ & 20.00 & $32.5 \mathrm{a}$ & 195.70 & 18.13 & 3.16 & 144.10 \\
\hline & $\mathrm{I}_{2} \mathrm{~S}_{2}$ & $153.74 \mathrm{c}$ & 16.33 & $24.9 \mathrm{ef}$ & 175.96 & 16.60 & 2.63 & 130.03 \\
\hline & $\mathrm{I}_{2} \mathrm{~S}_{3}$ & $138.18 \mathrm{e}$ & 11.00 & $27.75 \mathrm{~cd}$ & 163.93 & 15.33 & 2.49 & 108.33 \\
\hline & $\mathrm{I}_{2} \mathrm{~S}_{4}$ & $107.12 \mathrm{~g}$ & 13.33 & $19.5 \mathrm{~h}$ & 110.86 & 16.26 & 2.47 & 100.40 \\
\hline & $\mathrm{I}_{3} \mathrm{~S}_{1}$ & $157.3 b$ & 22.66 & $29 b c$ & 192.56 & 16.70 & 2.65 & 126.06 \\
\hline & $\mathrm{I}_{3} \mathrm{~S}_{2}$ & $139.98 \mathrm{e}$ & 17.33 & $22.5 \mathrm{~g}$ & 165.86 & 17.50 & 2.51 & 117.66 \\
\hline & $\mathrm{I}_{3} \mathrm{~S}_{3}$ & $133.28 \mathrm{f}$ & 14.33 & $25.75 \mathrm{ef}$ & 155.50 & 14.16 & 2.34 & 116.66 \\
\hline & $\mathrm{I}_{3} \mathrm{~S}_{4}$ & $109.1 \mathrm{~g}$ & 16.00 & $17 \mathrm{i}$ & 107.93 & 14.96 & 2.44 & 107.96 \\
\hline & LSD & 3.078 & NS & 1.83 & 7.30 & NS & NS & NS \\
\hline \multirow[t]{4}{*}{2015} & $\mathrm{I}_{1}$ & $129.77 b$ & 15.00 & $22.01 \mathrm{~b}$ & $157.95 b$ & 16.23 & 2.63 & $105.29 b$ \\
\hline & $\mathrm{I}_{2}$ & $136.18 \mathrm{a}$ & 15.33 & $23.24 \mathrm{a}$ & $163.35 \mathrm{a}$ & 16.55 & 2.64 & $117.50 \mathrm{a}$ \\
\hline & $\mathrm{I}_{3}$ & $125.27 \mathrm{c}$ & 17.58 & $22.075 b$ & $152.6 \mathrm{c}$ & 16.35 & 2.50 & $115.92 \mathrm{a}$ \\
\hline & LSD & 2.612 & NS & 0.2 & 1.04 & NS & NS & 6.94 \\
\hline
\end{tabular}




\begin{tabular}{lccccccc}
\hline $\mathrm{S}_{1}$ & $151.89 \mathrm{a}$ & $21.33 \mathrm{a}$ & $29.38 \mathrm{a}$ & $192.32 \mathrm{a}$ & $17.62 \mathrm{a}$ & $2.95 \mathrm{a}$ & $129.47 \mathrm{a}$ \\
$\mathrm{S}_{2}$ & $138.89 \mathrm{~b}$ & $16.44 \mathrm{~b}$ & $19.951 \mathrm{c}$ & $174.88 \mathrm{~b}$ & $16.43 \mathrm{~b}$ & $2.63 \mathrm{~b}$ & $113.83 \mathrm{~b}$ \\
$\mathrm{~S}_{3}$ & $123.64 \mathrm{c}$ & $12.22 \mathrm{c}$ & $24.367 \mathrm{~b}$ & $157.95 \mathrm{c}$ & $15.17 \mathrm{c}$ & $2.30 \mathrm{c}$ & $104.27 \mathrm{~b}$ \\
$\mathrm{~S}_{4}$ & $107.71 \mathrm{~d}$ & $13.88 \mathrm{c}$ & $16.07 \mathrm{~d}$ & $106.7 \mathrm{~d}$ & $16.28 \mathrm{~b}$ & $2.49 \mathrm{~b}$ & $104.04 \mathrm{~b}$ \\
$\mathrm{LSD}$ & 5.99 & 1.86 & 0.166 & 1.19 & 0.52 & 0.17 & 14.44 \\
\hline $\mathrm{I}_{1} \mathrm{~S}_{1}$ & $149.84 \mathrm{~b}$ & 21.00 & $28.9 \mathrm{~b}$ & $190.77 \mathrm{~b}$ & 17.30 & 2.92 & 119.66 \\
$\mathrm{I}_{1} \mathrm{~S}_{2}$ & $139.36 \mathrm{bcd}$ & 14.66 & $19.65 \mathrm{gh}$ & $178.27 \mathrm{~d}$ & 16.30 & 2.76 & 101.22 \\
$\mathrm{I}_{1} \mathrm{~S}_{3}$ & $121.67 \mathrm{ef}$ & 11.66 & $24.2 \mathrm{e}$ & $158.43 \mathrm{~g}$ & 15.30 & 2.34 & 96.57 \\
$\mathrm{I}_{1} \mathrm{~S}_{4}$ & $108.21 \mathrm{~g}$ & 12.66 & $14.96 \mathrm{k}$ & $105.33 \mathrm{j}$ & 16.03 & 2.51 & 103.73 \\
$\mathrm{I}_{2} \mathrm{~S}_{1}$ & $162.28 \mathrm{a}$ & 20.33 & $31.08 \mathrm{a}$ & $198.7 \mathrm{a}$ & 18.10 & 3.19 & 142.90 \\
$\mathrm{I}_{2} \mathrm{~S}_{2}$ & $141.52 \mathrm{bc}$ & 17.33 & $20.12 \mathrm{~g}$ & $177.9 \mathrm{~d}$ & 15.93 & 2.68 & 124.33 \\
$\mathrm{I}_{2} \mathrm{~S}_{3}$ & $130.08 \mathrm{de}$ & 11.33 & $23.85 \mathrm{f}$ & $165.9 \mathrm{f}$ & 15.40 & 2.29 & 102.16 \\
$\mathrm{I}_{2} \mathrm{~S}_{4}$ & $110.85 \mathrm{fg}$ & 12.33 & $17.92 \mathrm{i}$ & $110.88 \mathrm{i}$ & 16.80 & 2.42 & 100.60 \\
$\mathrm{I}_{3} \mathrm{~S}_{1}$ & $143.56 \mathrm{bc}$ & 22.60 & $28.17 \mathrm{c}$ & $187.5 \mathrm{c}$ & 17.46 & 2.74 & 125.86 \\
$\mathrm{I}_{3} \mathrm{~S}_{2}$ & $134.29 \mathrm{~cd}$ & 17.33 & $19.75 \mathrm{~h}$ & $168.8 \mathrm{e}$ & 17.06 & 2.46 & 115.93 \\
$\mathrm{I}_{3} \mathrm{~S}_{3}$ & $119.15 \mathrm{f}$ & 13.66 & $25.05 \mathrm{~d}$ & $150.5 \mathrm{~h}$ & 14.83 & 2.90 & 114.10 \\
$\mathrm{I}_{3} \mathrm{~S}_{4}$ & $104.08 \mathrm{~g}$ & 16.66 & $15.33 \mathrm{j}$ & $103.9 \mathrm{j}$ & 16.03 & 2.54 & 107.80 \\
$\mathrm{LSD}$ & 10.37 & $\mathrm{NS}$ & 0.287 & 2.06 & $\mathrm{NS}$ & $\mathrm{NS}$ & $\mathrm{NS}$ \\
\hline
\end{tabular}

Note: Numbers followed by different letters within the growing season are statistically different (P $\leq 0.05)$.

The number of leaves showed that for the first season there was significant difference between soil conditioners, and the interactions between lateral drip types and soil conditioners, while there was no significant difference between lateral drip types. For the second season, there was a significant difference in number of leaves among lateral drip types, soil conditioners, and the interactions between them.

Concerning with the interaction, results showed that number of leaves achieved the highest value (33 leaves) under compost with GR anti-roots $\left(\mathrm{I}_{2} \mathrm{~S}_{1}\right)$, and the lowest value (15 leaves) under GR with control $\left(\mathrm{I}_{1} \mathrm{~S}_{4}\right)$, for the first season, while the highest value (31 leaves) for $\left(\mathrm{I}_{2} \mathrm{~S}_{1}\right)$, and the lowest values was (15 leaves) for $\left(\mathrm{I}_{1} \mathrm{~S}_{4}\right)$, for the second season (Table 8).

The leaves area per plant under drip tapes, the highest value was (161.6 $\mathrm{cm}^{2}$ ), and the lowest value of leaves areas $\left(155.46 \mathrm{~cm}^{2}\right)$ for $\mathrm{I}_{2}$ and $\mathrm{I}_{3}$ treatments, respectively, for the first season, while the highest value was $\left(162.3 \mathrm{~cm}^{2}\right)$, and the lowest value $\left(152 \mathrm{~cm}^{2}\right)$ for GR anti-root $\left(\mathrm{I}_{2}\right)$ and Ttape $\left(\mathrm{I}_{3}\right)$ treatments, respectively, for the second season. For soil 
conditioners, the compost $\left(\mathrm{S}_{1}\right)$ treatment was higher by $10 \%, 19 \%$, and $43 \%$ in leaves areas comparing with rice straw $\left(S_{2}\right)$, polymer $\left(S_{3}\right)$ and control $\left(\mathrm{S}_{4}\right)$ treatments (control) for the first season, while the compost $\left(\mathrm{S}_{1}\right)$ was higher than $\left(\mathrm{S}_{2}\right),\left(\mathrm{S}_{3}\right)$ and $\left(\mathrm{S}_{4}\right)$ by $9.1 \%, 18 \%$, and $44.5 \%$, respectively for the second season (Table 8 ).

The interaction between the lateral drip types and soil conditioners, the highest values of leaves areas $\left(196 \mathrm{~cm}^{2}\right)$, and the lowest values of leaves areas $\left(107 \mathrm{~cm}^{2}\right)$ for $\left(\mathrm{I}_{2} \mathrm{~S}_{1}\right)$ and $\left(\mathrm{I}_{3} \mathrm{~S}_{4}\right)$ treatments, respectively, for the first season, while the highest values was $\left(198.7 \mathrm{~cm}^{2}\right)$, and the lowest values $\left(104 \mathrm{~cm}^{2}\right)$ for $\left(\mathrm{I}_{2} \mathrm{~S}_{1}\right)$ and $\left(\mathrm{I}_{3} \mathrm{~S}_{4}\right)$ treatments, respectively, for the second season (Table 8 ).

The outcomes displayed that, there was significant difference in fruit length among soil conditioners for both growing seasons, but there was no significant difference among lateral drip tapes and the interferences between lateral drip tapes and soil conditioners for both grown seasons.

For lateral drip tapes, the highest value of fruit length $(16.6 \mathrm{~cm})$, and the lowest value of fruit length $(15.8 \mathrm{~cm})$ were detected under $I_{2}$ and $I_{3}$ treatments, respectively, for the first season, while the highest value was $(16.5 \mathrm{~cm})$, and the lowest value $(16.2 \mathrm{~cm})$ for $I_{2}$ and $I_{1}$, respectively, for the second season, for soil conditioners, there was $1.7 \%, 13.8 \%$, and $8.9 \%$ increase in fruit length in compost treatment $\left(S_{1}\right)$ comparing with rice straw $\left(\mathrm{S}_{2}\right)$, polymer $\left(\mathrm{S}_{3}\right)$ and control $\left(\mathrm{S}_{4}\right)$ for the first season, while compost was higher than rice straw $\left(\mathrm{S}_{2}\right)$, polymer $\left(\mathrm{S}_{3}\right)$ and control $\left(\mathrm{S}_{4}\right)$ treatment by $6.7 \%, 14 \%$, and $7.6 \%$, respectively, for the second season.

The interaction between the lateral drip tapes and soil conditioners showed that the highest values of fruit length $(18.1 \mathrm{~cm})$, and the lowest values of leaves areas $(14.1 \mathrm{~cm})$ for compost with $\mathrm{GR}$ anti-roots $\left(\mathrm{I}_{2} \mathrm{~S}_{1}\right)$ and polymer with GR $\left(\mathrm{I}_{1} \mathrm{~S}_{3}\right)$ treatments, respectively, for the first season, while the highest values was $(18 \mathrm{~cm})$, and the lowest values $(15 \mathrm{~cm})$ for $\left.\mathrm{I}_{2} \mathrm{~S}_{1}\right)$ and $\left(\mathrm{I}_{3} \mathrm{~S}_{3}\right)$ treatments, respectively, for the second season (Table 8).

There was significant difference in fruit diameter among soil conditioners for both growing seasons, but there was no significant difference between lateral drip tapes, the interactions between lateral drip tapes and soil conditioners for both grown seasons. For lateral drip tapes, the highest values of fruit diameter $(2.7 \mathrm{~cm})$, and the lowest values of fruit diameter 
$(2.4 \mathrm{~cm})$ for GR anti-roots $\left(\mathrm{I}_{2}\right)$ and T-tape $\left(\mathrm{I}_{3}\right)$ treatments, respectively, for the first season, while the highest value was $(2.6 \mathrm{~cm})$, and the lowest value $(2.5 \mathrm{~cm})$ for $\mathrm{GR}$ anti-root $\left(\mathrm{I}_{2}\right)$ and T-tape $\left(\mathrm{I}_{3}\right)$ treatments, respectively, for the second season.

With respect to the soil conditioners, there was $9.4 \%, 16.7 \%$, and $14.6 \%$ increase in fruit diameter in $\left(S_{1}\right)$ comparing with rice straw $\left(S_{2}\right)$, polymer $\left(\mathrm{S}_{3}\right)$ and control $\left(\mathrm{S}_{4}\right)$ treatments, for the first season, while there was $10.8 \%, 22 \%$, and $15.6 \%$ increase in fruit diameter in $\left(\mathrm{S}_{1}\right)$ comparing with rice straw $\left(\mathrm{S}_{2}\right)$, polymer $\left(\mathrm{S}_{3}\right)$ and control $\left(\mathrm{S}_{4}\right)$ for the second season.

The interaction between the lateral drip tapes and soil conditioners, the highest values of fruit diameter $(3.1 \mathrm{~cm})$, and the lowest values of leaves areas $(2.34 \mathrm{~cm})$ for compost with GR anti-roots $\left(\mathrm{I}_{2} \mathrm{~S}_{1}\right)$ and polymer with T-tape $\left(I_{3} S_{3}\right)$ treatments, respectively, for the first season, while the highest values was $(3.2 \mathrm{~cm})$, and the lowest values $(2.3 \mathrm{~cm})$ for compost with GR anti-roots $\left(\mathrm{I}_{2} \mathrm{~S}_{1}\right)$ and polymer with $\mathrm{GR}\left(\mathrm{I}_{1} \mathrm{~S}_{3}\right)$ treatments, respectively, for the second season (Table 8).

With respect of fruit weightiness, there was a significant difference among soil conditioners, and lateral drip tapes, while there was no significant difference of interaction among lateral drip tapes and soil conditioners for both growing seasons (Table 8).

For lateral drip tapes, the highest and lowest values of fruit weight were $(120.7 \mathrm{~g})$ and $(98.7 \mathrm{~g})$, for GR anti-roots $\left(\mathrm{I}_{2}\right)$ and GR $\left(\mathrm{I}_{1}\right)$ treatments, respectively, for the first season, while the highest and lowest values of fruit weight were $(116.5 \mathrm{~g})$ and $(105.3 \mathrm{~g})$, for GR anti-roots $\left(\mathrm{I}_{2}\right)$ and GR $\left(\mathrm{I}_{1}\right)$ treatments, respectively, for the second season.

For soil conditioners, there was $11.8 \%, 18.2 \%$, and $22.2 \%$ increase in fruit weight in compost $\left(\mathrm{S}_{1}\right)$ treatment comparing with rice straw $\left(\mathrm{I}_{2}\right)$, polymers $\left(\mathrm{I}_{3}\right)$, and control $\left(\mathrm{I}_{4}\right)$ treatments, for the first season, while there was $12.1 \%, 19.5 \%$, and $19.6 \%$ increase in fruit weight in $\left(S_{1}\right)$ treatment comparing with $\left(\mathrm{I}_{2}\right),\left(\mathrm{I}_{3}\right)$, and $\left(\mathrm{I}_{4}\right)$ treatments, for the second season.

For the interaction between the lateral drip tapes and soil conditioners, the highest values of fruit weight $(130 \mathrm{~g})$, and the lowest values of fruit weight $(92 \mathrm{~g})$ for $\left(\mathrm{I}_{2} \mathrm{~S}_{2}\right) \mathrm{GR}$ anti-roots with compost and GR with polymer $\left(\mathrm{I}_{1} \mathrm{~S}_{3}\right)$ treatments, respectively, for the first season, while the highest and 
lowest values of fruit weight were (143 g) and (96.6 g) for $\left(\mathrm{I}_{2} \mathrm{~S}_{2}\right)$ and $\left(\mathrm{I}_{1} \mathrm{~S}_{3}\right)$, respectively, for the second season (Table 8).

The increase in the dimensions of the fruit (length and diameter) can be attributed to balanced nutrition, and improve the ability of the plant to absorb nutrients, which is composed of a high proportion of carbohydrates, this positive impact was achieved through a combination of adding organic and bio-fertilizers that effect on increasing of chlorophyll content in the leaves, which leading to increased photosynthesis and consequently increased fruit dimensions and so productivity (Umamaheshwarappa et al., 2005).

\section{CONCLUSIONS}

The use of soil conditioners in this research intended to improve the yield and water productivity and quality of cucumber crop in sandy soil. The main conclusions of this research are:

$\checkmark$ Compost application with subsurface drip tapes achieved higher yield, water productivity and made an improvement under salinity, especially with GR anti-roots drip tape.

$\checkmark$ In general, all soil conditioners, have a positive impact, whether in small or large degree on the physicochemical characteristics of the soil and on cucumber plants. The growth characteristics of cucumber were enhanced when adding compost to the soil.

$\checkmark$ There were no differences between any lateral drip tapes under soil conditions (GR, GR anti roots, and T-tape) on yield and plant growth and water productivity

$\checkmark$ The positive results related to soil conditioners were obtained under a small plot area (0.0432ha.) which support declared results acquired from experiments performed on a commercial farm, and are sufficiently heartening to warrant pursue field work on larger areas in sandy soil.

\section{REFERENCES}

Akelah, A., 2013. Functionalized polymeric Materials in Agriculture and the food Industry. Springer New York Heidelberg Dordrecht London. 
Akhter, J., Mahmood, K., Malik, K.A., Mardan, A., Ahmad, M., Iqbal, M.M., 2004. Effects of hydrogel amendment on water storage of sandy loam and loam soils and seedling growth of barley, wheat and chickpea. Plant Soil Environ, 50, 463-469.

Ali, H.I., Ismail, M.R., Manan, M.M., Saudi, H.M., 2006. Rice straw compost and water deficit affect yield, quality and water productivity of tomatoes grown in different media. Biol. Agric. Hortic., 24: 301-316.

Al-Omrana, A. M., Shetaa, A. S., Falataha, A. M., Al-Harbib, A. R., 2004. Effect of drip irrigation on squash (Cucurbita Pepo) yield and water productivity in sandy calcareous soils amended with clay deposits. Agricultural Water Management, 73: 43-55.

Aly, H.H., 2002. Studies on keeping quality and storage ability of cucumber fruits under organic farming system in plastichouses.MSc Thesis, Hort. Dept., Cairo Univ., Egypt.

ASAE. 1996a. Field Evaluation of Micro Irrigation Systems.EP405.1. ASAE Standards. Amer. Soc. Agric. Engr., St. Joseph, MI, pp. 756759.

ASAE. 1996b. Design and Installation of Micro Irrigation Systems. EP409. ASAE Standards. Amer. Soc. Agric. Engr., St. Joseph, MI, pp. 792-797.

Baybordi, Y.M., Malakooti, M.J., AmiriMakri, H., Nafisi, M., 2000. Production and consumption of chemical fertilizers according to sustainable agriculture aims. Agricultural education publication. Iran.

Bhushan, L., Ladha, J.K., Gupta, R.K., Singh, S., Tirol-Padre, A., Saharawat, Y.S., Gathala, M., Pathak, H., 2007. Saving of water and labor in a rice-wheat system with no-tillage and direct seeding technologies. Agron. J 99, 1288-1296.

Caravaca, F., Hernandez, T., Garcia, C., Roldan, A., 2002. Improvement of rhizosphere aggregate stability of afforested 
semiarid plant species subjected to mycorrhizal inoculation and compost addition. Geoderma, 108: 133-144.

Carmassi, G., Bacci, L., Bronzini, M., Incrocci, L., Maggini, R., Bellocchi, G., Massa, D., Pardossi, A., 2013. Modelling transpiration of greenhouse gerbera (Gerberajamesonii H. Bolus) grown in substrate with saline water in a Mediterranean climate. Sci. Hortic. 156, 9-18.

Chen, W., Hou, Z., Wu, L., Liang, Y., Wei, C., 2010. Evaluating salinity distribution in soil irrigated with saline water in arid regions of northwest China. Agric. Water Manage. 97, 2001-2008.

Cook, A.G.A., Kceling, A.A., Bloxham, P.F., 1998. Effect of green waste compost on yield parameters in spring Barley (Hordeumvulgare). Acta Hort, 467: 283- 286.

David, w., Adrian, C., Carl, W., 2011. Managing Soil Tilth Texture, Structure and Pore Space. PhD. Colorado State University Extension.

Davies, D.H.K., Drysdale, A., McKinlay, R.J., Dent, J.B., Williams, G.H., 1993. Novel approaches to mulches for weed control in vegetables, Proc. of a Conf. on Crop Protection in North. Britain, Dundee 23-25 March, pp: 271-276.

Dewis, J., Fartias, 1970. Physical and Chemical Methods of Soil and Water Analysis. Soil Bulletin No. 10, FAO, Rome.

El-Berry, A. M., Afifi, M.A., Ahmed, M.H., 1989. Effects of irrigation system on moisture pattern productivity and harvesting of fodder in arid lands. Misr J. Ag. Eng., 6(4): 359-371.

El-Gindy, A.M., Abdel-Mageed, H.N., El-Adl, M.A., Mohamed, E.M.K., 2001. Management of pressurize irrigated faba bean in sandy soil. Misr J. Ag. Eng., Vol.18 (1): 29-44.

Esawy, M., Ibrahim, M., Robin, P., Akkal-Corfini, N., El-Saka, M., 2009. Rice straw composting and its effect on soil properties. Compost Sci. Utilization, 17(3): 146-150. 
Ferguson J.L., 2001. Evaluation the on farm composting of waste. Fur Breeders. Agricultural Co-Op summer school. August 11- Park city. Utah, USA.

Ghasem S., Morteza A.S., Maryam T., 2014. Effect of organic fertilizers on cucumber (Cucumissativus) yield. International Journal of Agriculture and Crop Sciences, 7 (11): 808-814.

Greer, L., Diver, S., 2000. Organic Greenhouse Vegetable Production, Horticulture Production Guide, Appropriate Technology Transfer for Rural Areas, Fayetteville, 31 p.

Hanson, B., May, D., 2004. Effect of subsurface drip irrigation on processing tomato yield, water table depth, soil salinity, and profitability. Agriculture Water Management. 68, 1-17.

Heikal, H.A.M., El-Sherbiny, W.A., Ghodia, R.H., 2008. Effect of irrigation system and compost addition on potato yield and calcareous soil-physical properties. The 15th.Annual Conference of the Misr Society of Ag. Eng. 425-444.

Hesse, P.R., 1971. A Text Book of Soil Chemical Analysis. Juan Murry (Publisher) Ltd, London.

Jackson, M.L., 1967. Soil Chemical Analysis. Printic Hall of India, New Delhi.

Jose O.P., Tarkalson, D.D., Irmak, S., Davison, D., Petersen, J.L., 2008. Effect of irrigation amounts applied with subsurface drip irrigation on corn evapotranspiration, yield, water productivity, and dry matter production in a semiarid climate. Publications from USDA-ARS/UNL Faculty Paper 199.

Keller, J., Karmeli, D., 1975. Trickle irrigation design. Rain Bird Sprinkler Manufacturing Corporation, Glendora, CA, 133p.

Klute, A., 1986. Methods of Soil Analysis. American Society of Agron., Inc. Madison, Wisconsin, USA.

Lakhdar, A., Hafsi, C., Debez, A., Montemurro, F., Jedidi, N., Abdelly, C., 2011. Assessing solid waste compost application as a 
practical approach for salt-affected soil reclamation. Acta Agric. Scand. Sect. Soil Plant Sci. 61,284-288.

Lakhdar, A., Hafsi, C., Rabhi, M., Debez, A., Montemurro, F., Abdelly, C., Jedidi, N., Ouerghi, Z., 2008. Application of municipal solid waste compost reduces thenegative effects of saline water in Hordeummaritimum L. Bioresour. Technol.99, 7160-7167.

Lakhdar, A., Rabhi, M., Ghnaya, T., Montemurro, F., Jedidi, N., Abdelly, C., 2009. Effectiveness of compost use in salt-affected soil. J. Hazard. Mater. 171, 29-37.

Melero, S., Madejon, E., Ruiz, J. C., Herencia, J. F., 2007. Chemical and biochemical properties of a clay soil under dryland agriculture system as affected by organic fertilization. Eur. J. Agron. 26: 327 334.

Moyin-Jesu, E.I., Ojeniyi, S.O., 2006. Effects of sole and amended plant residues on soil nutrient contents and yield of Okra (Abelimoschusesculentum L.). Discovery and Innovation Journal. 18(4): 318-326.

Mylavarapu R.S., Zinati G.M., 2009. Improvement of soil properties using compost for optimum parsley production in sandy soils. Scientia Horticulturae, 120, 426-430.

Neufeld, J., Davison, J., Stevenson, T., 1999. Subsurface drip irrigation, Nevada cooperative extension, Fact Sheet 97-13, University of Nevada, Reno.

Richards, L.A., 1954. Diagnosis and improving of saline and alkaline soils. U.S. Salinity Laboratory Staff. Agric. Handbook, No. 60.

Roe, N.., Stoffella, P.J., Graetz, D., 1997. Composts from various municipal solid waste feed stocks affected vegetable crops. 2: Growth, yields and fruit quality. J. Amer. Soc. Hort. Sci., 122: 433-437.

Schaumberger, A., Loiskandl, W., 2010. Assessment of SoilAmendment Mixtures for Subsurface Drip Irrigation Systems. Institute of Hydraulics and Rural Water Management, University of 
Natural Resources and Applied Life Sciences (BOKU), Vienna, Austria.

Shahrokhian, Z., Mirzaei, F., Hashemitame, M., 2013. Supper Absorbent Polymer Effect on Available Water-Holding Capacity of Soils and Soil Water Retention Curve and Van Genuchten model Assessment. International Journal of Agronomy and Plant Production. 4(11): 2856-2865.

Suganya, S., Sivasamy, R., 2006. Moisture retention and cation exchange capacity of sandy soil as influenced by soil additives. $\mathbf{J}$ Appl. Sci. Res. 2:949-951.

Tejada, M., Garcia, C., Gonzalez, J.L., Hernandez, M.T., 2006. Use of organic amendment as a strategy for saline soil remediation: influence on the physical, chemical and biological properties of soil. Soil Biol. Biochem. 38, 1413-1421.

Umamaheshwarappa, P., Nachegowda, V., Murthy, P.V., 2005. Uptake of nitrogen, phosphorous, potassium and fruit size of cucumber Cv. Poinsette as influenced by different levels of NPK fertilizers. Karnataka J. Hort., 1(3): 76-80.

Valdez-Aguilar, L.A., Grieve, C.M., Poss, J.A., 2013. Response of lisian thus to irrigation with saline water: plant growth. J. Plant Nutr. 36, 1605-1614.

Vomocil, J. A., 1957. Measurements of soil bulk density and penetrability. A Review of Methods Adv. Agron., 9: 159-176.

Walker, D.J., Bernal, M.P., 2008. The effects of olive mill waste compost and poultry manure on the availability and plant uptake of nutrients in a highly saline soil. Bioresources Technology. 99, 396403.

Wang, Z., Liu, Z., Zhang, Z., Liu, X., 2009. Subsurface drip irrigation scheduling for cucumber (Cucumissativus L.) grown in solar greenhouse based on $20 \mathrm{~cm}$ standard pan evaporation in Northeast China. Scientia Horticulturae, 123, 51-57. 
Zhang, J., Chen, H., Li, P., Wang, A., 2006. Study on superabsorbent composite Preparation of polyacrylic acid/organo-attapulgite composite hydrogels and swelling behaviors in aqueous electrolyte solution. Macromol. Mat. Eng. 2006, 291, 1529-1538.

\section{الملخص العربي - n}

تأثير أستخدام محسنات التربة على أنتاجية، كفاعة أستخدام المياه

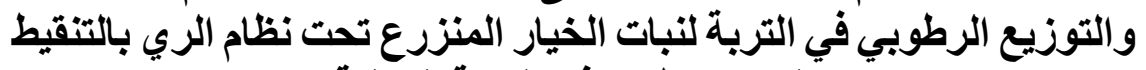
التحت سطحي في التربة الرملية

محمد السيد ابوعرب "، أمل محمد عبد الحميد، وائل سلطان ** و محمد عبدالوهاب قاسم**** تم إجر اء تجربة ميدانية في تربة رملية بأحد المزارع الخاصة بمحافظة الجيزة، خلال موسمين

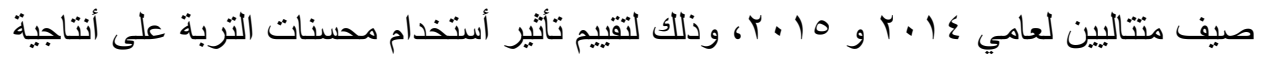

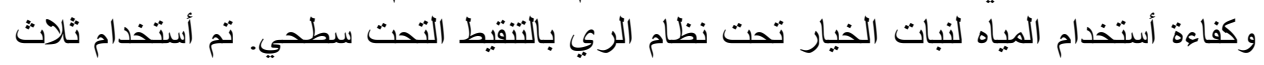

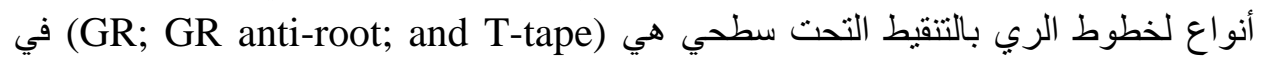

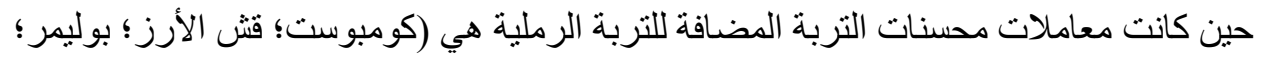
و التربة الرملية بدون أي إضافات لمحسنات التربة).

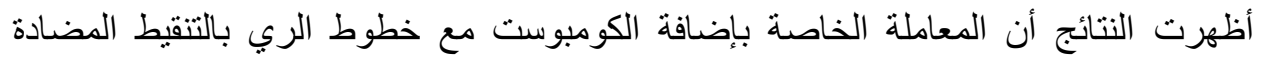

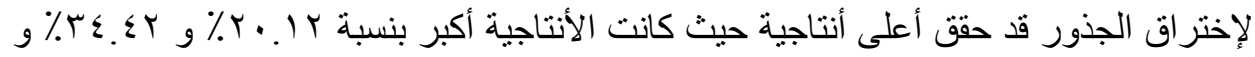

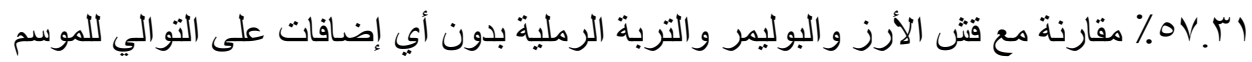

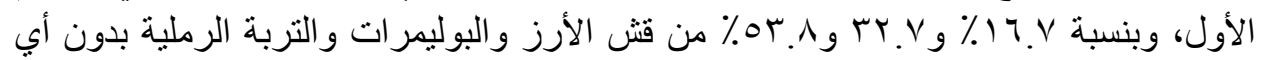

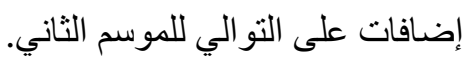

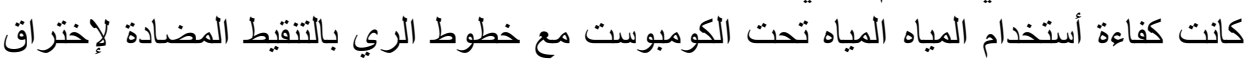

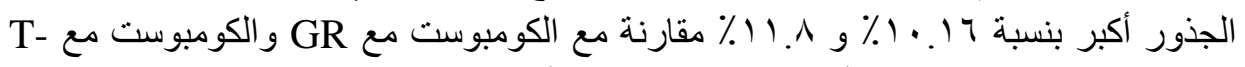

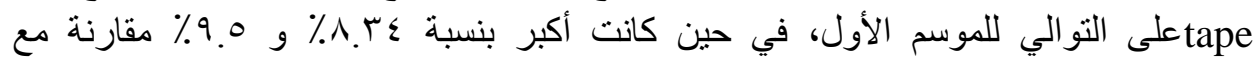

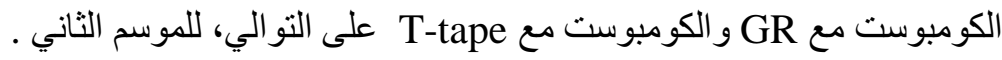

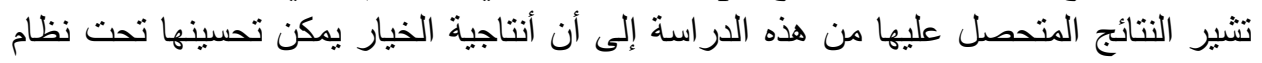

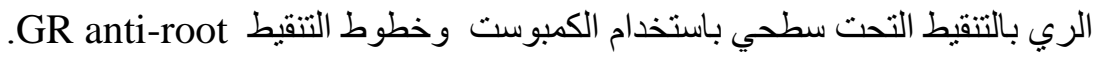

* أستاذ الهندسة الزراعية المساعد ـ كلية الزراعة ـ جامعة القاهرة.

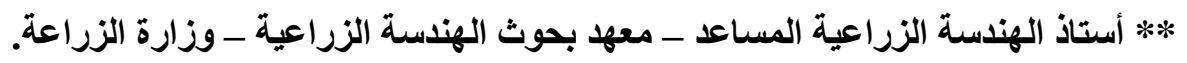
** ** أستاذ الهندسة الزراعية ـ كلية الزراعة ـ جامعة القاهرة. 